\title{
Application of Antimicrobial Bacillus subtilis Strain as a Starter Culture to Improve Qualities and Safety of Fermented Soybean (SIENG) Produced in Cambodia
}

\author{
Ek Sopheap ${ }^{1}$, Huon Thavrak ${ }^{2}$, Buntong Borarin ${ }^{3}$, Chay Chim $^{1}$ and Yasuhiro Inatsu ${ }^{4}$ \\ 1. Faculty of Agro-Industry, Royal University of Agriculture, Phnom Penh 12000-12401, Cambodia \\ 2. Graduate Schools, Royal University of Agriculture, Phnom Penh 12000-12401, Cambodia \\ 3. Division of Research and Extension, Royal University of Agriculture, Phnom Penh 12000-12401, Cambodia \\ 4. Food Safety Division, National Food Research Institute, Tsukuba, Ibaraki 305-8642, Japan
}

\begin{abstract}
Fermented foods play a very important role in Cambodian health and nutrition, as well as other developing countries where food preservation methods may be limited. SIENG, a Khmer fermented soybean product, naturally contains both beneficial and pathogenic microorganisms. Traditional fermentation that relies on natural microbial flora and environmental conditions results in variable product quality and can lead to spoilage. A starter culture such as Bacillus subtilis can ensure the safety and stability of the products. The objective of this study is to control the growth of Gram positive pathogens contaminated into traditional fermented soybean (SEING) by using antimicrobial Bacillus subtilis isolated from the same kind of food. Out of 120 SIENG samples, 49 B. cereus strains were isolated, and 12 of $B$. cereus were positively synthesized compared with the lyophilized control enterotoxin. Two of these strains (BTM8-7 and BTM8-8) produced high levels of enterotoxin. We identified five Bacillus strains with the ability to fight against indicator pathogenic microorganisms. Among the five strains, B. CeM6-2 had the highest activity level against Lactobacillus plantrum ATCC 8014 and the largest diameter. B. CeM6-2 tolerated up to $20 \mathrm{~h}$ at $30{ }^{\circ} \mathrm{C}$ and $22 \mathrm{~h}$ at $37^{\circ} \mathrm{C}$. In testing the strains with PK and PK-PMSF enzymes, bacteriocin produced by the strain B. CeM6PK untreated and B. CeM6-2PK-PMSF had a significantly stronger ability to suppress all the pathogenic indicators from $0 \mathrm{~h}$ to $47 \mathrm{~h}$ compared to the $B$. CeM6-2PK. Moreover, CeM6-2 outperformed the Miyagino strains, as it actively produced bacteriocin that fought against all four indicator strains of Gram positive and lactic acid groups, especially against Listeria monocytogenes, Streptococcus pyrogene, Leuconostoc mesenterids and $L$. plantarum, from $0 \mathrm{~h}-58 \mathrm{~h}$ and $0 \mathrm{~h}-40 \mathrm{~h}$ at $35^{\circ} \mathrm{C}$. CeM6-2 (1\%) strain had the highest ability to fight against B. cereus at $24 \mathrm{~h}$ and at $34 \mathrm{~h}$ to $44 \mathrm{~h}$ incubation as well. CeM6-2 (10:0 mL) and CeM6-2 (9:1 mL) have the strongest ability to fight against $B$. cereus at room temperature (48 h and $72 \mathrm{~h}$ ). The longer incubation and time at room temperature produce the highest level of bacteriocin. Thus, bacteriocins produced by B. CeM6-2 can be used as a preservative in food processing industries to avoid food spoilage even in higher temperatures and time.
\end{abstract}

Key words: SIENG (Khmer traditional fermented soybean), soybean, fermentation, bacteriocin, Bacillus subtilis, Bacillus cereus, pathogens, spoilage, microorganism.

\section{Introduction}

Food is the most important basic need of all living on earth. In recent year's health-consciousness consumers prefer for natural foods without chemical preservatives to fit in their healthy lifestyle. According to health and food safety experts more than 200

Corresponding author: Ek Sopheap, M. Eng., vince dean and researcher, research fields: grain quality and food safety. known diseases are transmitted through contaminated food and masses of illness cases annually by food-borne pathogens [1]. Bacillus cereus has been detected and implicated in contaminated foods containing fermented soybeans, and numerous outbreaks of food poisoning have been caused by $B$. cereus [2]. B. cereus toxins in these products, and the symptoms of $B$. cereus diarrheal type food poisoning, including abdominal pain, cramps, nausea, and rarely 

and Safety of Fermented Soybean (SIENG) Produced in Cambodia

vomiting and watery diarrhea occur at $8 \mathrm{~h}$ to $16 \mathrm{~h}$ after ingestion of contaminated food [3]. Though Cambodia is the third world country, Royal Government of Cambodia is also considering to reduce foodborne disease and improve public health status by introducing food safety standards and market regulation into food industries [4].

Fermented foods are commonly found in Cambodia and in other Asia countries since they play a very important role for health. In fact, soybean has been produced into fermented soybean, commonly called SIENG, and there are two kinds of fermented SIENG in Cambodia, we called SIENG PRAI and SIENG $P A-A E M$. They are very famous and healthy foods among other Cambodian's soybean processed products [5]. Bacillus subtilis may be present on the soybean seed during cultivation or contaminate in SIENG during process according to Cambodia production context where SIENG is fermented using a pure starter strain of $B$. subtilis, naturally occurring microorganisms or seeds (a portion of the product) used to produce fermented soybeans in other Asian countries [6]. B. subtilis has been reported to produce bacteriocins which suppress the growth of Gram positive spoilage and pathogenic bacteria [7, 8]. The bacteriocins produced by these strains are thought to be potent food preservatives that are applicable for Cambodian food. Bacteriocins produced by industrial important B. subtilis, have a history of safe use in food and industry [9].

Recent studies have recommended that the antibacterial substances produced by isolated bacterial strains may be applied to industrial-scale fermented soybean foods. B. subtilis has extensively been used to inhibit the growth of foodborne pathogens, particularly in the production of fermented and non-fermented foods. Nevertheless, the preservation of foods by natural and microbiological methods may be a satisfactory approach solving economic losses due to microbial spoilage of raw materials and food products, to reduce the incidence of food borne illnesses, and to meet the food requirements of the growing world population. The bacteriocins produced by these strains are thought to be potent food preservatives that are applicable and useful for Cambodian food industry.

\section{Material and Methods}

\subsection{Bacillus cereus Isolation and Checking the Contamination Rate of Toxin}

One hundred and twenty fermented soybeans samples were purchased from local market in Cambodia. Each of samples of SEING was one loop inoculated in NB medium and incubated for 2 days, $35{ }^{\circ} \mathrm{C}$. Then, culture was streaked on NGKG $(\mathrm{NaCl}$ glycine Kim and Goepfert) agar plate to isolate typical colonies of Bacillus cereus and suspected colonies were confirmed by Gram staining and biochemical test and finally were confirmed by analytical profile index (API 50CHB V4.1). Identify Bacillus cereus toxin genes by PCR method: there were 2 steps conducted in PCR and well diffusion assay. The first will use exactly the CRET-RPLA for enterotoxin and second PCR reaction testing method [10].

\subsection{Isolation and Screening Bacteriocin Producing Bacillus subtilis Strains}

One hundred and twenty fermented soybeans samples were purchased from local market in Cambodia. Each of samples was mixed with 10 times volume of nutrient broth and incubated at $35{ }^{\circ} \mathrm{C}$ for 18 h. The culture was streaked on nutrient agar plate to isolate typical colonies of $B$. subtilis. All Bacillus strains that have ability to inhibit the grow of indicators from the previous step were streaked into GSP and Mannitol salt agar plate, incubated at $35{ }^{\circ} \mathrm{C}$ for 24-48 h, and isolated bacteria were identified by Gram staining and biochemical tests using catalase/OF test and finally were confirmed by API.

Antimicrobial activity against indicator organisms was determined by using a well diffusion assay. There were 3 steps conducted in well diffusion assay. The 


\section{Application of Antimicrobial Bacillus subtilis Strain as a Starter Culture to Improve Qualities and Safety of Fermented Soybean (SIENG) Produced in Cambodia}

first and second were used exactly the same testing method. However, either the first or second testing is of minor difference with the third one specifically on (1) with filtration, and (2) without filtration. One loop of each of the spore suspension of isolated $B$. subtilis strains was inoculated into $5 \mathrm{~mL}$ of LB broth and incubated at $35{ }^{\circ} \mathrm{C}$ for $18 \mathrm{~h}$. Filtered culture supernatant was subjected to agar well diffusion assay. Lactobacillus plantarum ATCC 8014 was used for indicating bacteria and B. subtilis, Miyagino strains (used for Natto production) were used for negative control, respectively.

\subsection{Characterize the Bacteriocin Produced by Isolated Strain}

2.3.1 Incubator Temperature and Timing Treatment The spore culture of bacteriocin produced by $B$. subtilis strain was determined. One loop of the spore suspension of isolated $B$. subtilis strain was transferred to $5 \mathrm{~mL}$ of LB broth and kept on incubator shaker at $35^{\circ} \mathrm{C}, 72 \mathrm{~h}$, and then was heated and cooled down. There were 2 steps conducted in well diffusion assay as follows:

A total of $0.5 \mathrm{~mL}$ was transferred into $100 \mathrm{~mL}$ aliquots flasks of sterile composed LB broth. Then, the flasks were incubated in 2 deference incubator shakers. In both started at 7:00 AM, and 17:00 PM the flasks were incubated at $30{ }^{\circ} \mathrm{C}$ and $35{ }^{\circ} \mathrm{C}$, then take 1 $\mathrm{mL}$ of individual sample respectively at each different timing 6, 8, 10, and $12 \mathrm{~h}$ and 12, 14, 16, 18, 20, and $22 \mathrm{~h}$ to transfer into micro-centrifuge tubes.

L. plantarum was inoculated into the mixture (1:1 volume) of MRS broth contained supplement agar and keep it till become solid and make wells, and then filtered culture supernatant of B. subtilis or Miyagino strain and incubated $24 \mathrm{~h}, 30^{\circ} \mathrm{C}$. Growth of inoculated L. plantarum in this MRS broth was measured and observed length of wells by $\mathrm{mm} / \mathrm{mL}$.

\subsubsection{Enzyme Treatment (Indicator Strain LP)}

The sensitivity of the bacteriocin to enzymes was checked by using a well diffusion assay. B. subtilis and Miyagino strain for control were inoculated into a $30 \mathrm{~mL}$ of LB broth and placed on the incubator shaker at $30{ }^{\circ} \mathrm{C}$ on $250 \mathrm{rpm}$ for overnight.

Five (5) $\mathrm{mL} L$. plantum $(L P)$ was transferred to MRS and LB broth and incubated at $30^{\circ} \mathrm{C}$ and $35^{\circ} \mathrm{C}$, overnight and after shaker measure turbidness at $\mathrm{OD}$ $650 \mathrm{~nm}$ and dilute until OD 0.1 by PBS all of strains, into the mixture (1:1 volume) of PK and PK-PMSF and filtered culture supernatant of $B$. subtilis or Miyagino strains, is kept in bioplotter and incubated 24 hours at $35{ }^{\circ} \mathrm{C}$. Following the incubation, length of wells was observed. The antagonistic activity in OD $650 \mathrm{~nm}$ was calculated as a measure of bacteriocin production.

2.4 Apply the Bacteriocin to Control the Growth of Gram Positive Pathogenic or Spoilage Bacteria in Foods

Bacteriocin to control the growth of Gram positive pathogenic or spoilage bacteria in foods was applied by using a well diffusion assay. There were 2 kinds of Bacillus subtilis strains, (1) B. subtilis (Cambodia) and (2) Miyagino for control (Japan). Each strain was inoculated into a $20 \mathrm{~mL}$ of LB broth centrifuge tubes and placed on the incubator shaker at $35{ }^{\circ} \mathrm{C}, 16 \mathrm{~h}$. Gram positive group (Enterococcus faecium, Listeria monocytogenes, Bacillus cereus, Streptococcus pyrogene, Micrococcus luteu and S. aureus) and lactic acid group (Lactobacillus brevis, Leuconostoc mesenterides, L. curvatus, Lactobacillus plantnum, Lc. lactis $(\mathrm{NinA}+)$ and Lactobacillus lactis) were inoculated separately to BHI and MRS in incubator shaker at $35{ }^{\circ} \mathrm{C}$ for 18 to $24 \mathrm{~h}$. After shaker measure turbidness at OD $650 \mathrm{~nm}$ and dilute until OD 0.1 by PBS all of strains.

Filtered culture supernatant of antimicrobial $B$. subtilis or Miyagino strains was mixed with same volume of MRS or BHI broth for lactic acid bacteria or other Gram-positive bacteria, respectively. Each of the pre-cultures of indicator strains was inoculated into this mixture and cultivated at $35{ }^{\circ} \mathrm{C}$. Change of 

and Safety of Fermented Soybean (SIENG) Produced in Cambodia

the optical density at $650 \mathrm{~nm}$ was recorded automatically.

2.5 Co-cultivate Bacillus cereus and Bacillus subtilis in a Tripticase Soy Broth or Soybean and Check the Suppression of the Growth of Bacillus cereus

This test will be designed by using broth dilution and/or counting methods which have percentage and timing to record the time as desired and follows:

For co-culture experiments, Bacillus cereuses and Bacillus subtilis (B. CeM6-2) were grown in nutrient broth and MRS broth for $24 \mathrm{~h}$ at $35^{\circ} \mathrm{C}$. And following the incubation time, both of Bacillus do the dilution with normal saline and adjust the density to reach $10^{6}$ to $10^{8}$ colony forming units (CFU)/mL by using spectrophotometer with the optical density at $600 \mathrm{~nm}$ (OD600) of the bacterial cells that reached approximately 0.1 of optical density.

Then, Bacillus cereus $10^{6}$ to $10^{8} \mathrm{CFU} / \mathrm{mL}$ with different concentrations of potential Bacillus subtilis (B. CeM6-2) isolates $(0.1 \%, 0.2 \%, 0.3 \%, 0.4 \%, 0.5 \%$, and $1 \%$ ), were co-inoculated in tripticase soy broth containing $B$. cereus $10^{6}$ to $10^{8} \mathrm{CFU} / \mathrm{mL}$ and then incubated for $24 \mathrm{~h}, 34 \mathrm{~h}$ and $44 \mathrm{~h}$ at $35^{\circ} \mathrm{C}$. After that, the cells remained in contact with the substance for different timing and the presence of growth and/or counts colonies by NGKG agar were considered a positive result.

2.6 Check the Quality of SEING Produced by Antimicrobial Bacillus subtilis Strain

Soybeans (500 g) were washed and soaked in clean or sterile potable water for $16 \mathrm{~h}$ at room temperature (RT). After draining the water, soaked soybean weight will be increased by approximately twofold. The drained soybeans were steamed at $100{ }^{\circ} \mathrm{C}$ for $3 \mathrm{~h}$ and cooled at $40{ }^{\circ} \mathrm{C}$. Then, B. cereus and potential $B$. CeM6-2 cultures were inoculated to a density of $10^{6}$ to $10^{8} \mathrm{CFU} / \mathrm{mL}(\mathrm{OD} 600=0.1)$ after $24 \mathrm{~h}$ incubation in $\mathrm{NB}$ and MRS broth at $30{ }^{\circ} \mathrm{C}$ to $35^{\circ} \mathrm{C}$ (the same process as the objective 3 ).
After cooling, the surfaces of the cooked soybean will be inoculated with $1 \%(\mathrm{v} / \mathrm{w}),\left(10^{6}\right.$ to $\left.10^{8} \mathrm{CFU} / \mathrm{g}\right)$ inoculum in the different radio:

(1) Mixed culture B. CeM6-2 and B. cereus in ratio 10:0 for control;

(2) Mixed culture B. CeM6-2 and B. cereus in ratio 0:10 for control;

(3) Mixed culture B. CeM6-2 and B. cereus in ratio 9:1 for treatment;

(4) Mixed culture B. CeM6-2 and B. cereus in ratio 1:9 for treatment;

(5) Mixed culture B. CeM6-2 and B. cereus in ratio 5:5 for treatment;

(6) Mixed culture B. CeM6-2 and B. cereus in ratio 7:3 for treatment;

(7) Mixed culture B. CeM6-2 and B. cereus in ratio 3:7 for treatment.

After that the mixtures were fermented at $35^{\circ} \mathrm{C}$ for $24 \mathrm{~h}, 48 \mathrm{~h}$ and $72 \mathrm{~h}$, and then the $B$. cereus was isolated from each treatment, the cells remained in contact with the substance for different timing and the presence of growth and/or counting colonies by NGKG agar will be considered a positive result to observe the suppression of the growth of Bacillus cereus on the fermented soybean.

\subsection{Data Processing and Analysis}

The results were analyzed by Excel, CFU/mL and OD. In analyzing data, both quantitative and qualitative methods were used, and other appropriate methods such as Preference Ranking and Indexing were also used.

\section{Results and Discussion}

3.1 Bacillus cereus Isolation and Checking the Contamination Rate of Toxin

One hundred and twenty (120) raw SIENG were isolated for Bacillus cereus strains. As a result, only a total of 49 samples (41\%) of Bacillus cereus strains were presented on the NGKG agar, whose colonies were white and slightly thick, as the medium around 


\section{Application of Antimicrobial Bacillus subtilis Strain as a Starter Culture to Improve Qualities and Safety of Fermented Soybean (SIENG) Produced in Cambodia}

colonies presents red. Bacillus cereus strains are potential of toxin production by B. cereus strains. To test with Gram reaction, oxidase, catalase, aerobic growth, anaerobic growth, VP are resulted positive. In starch hydrolyze test there is only thirty-seven (31\%) Bacillus cereus that presented negative, yet. Bacillus cereus, which was compared with positive indicator of Bacillus cereus presented positive. Also, as B. cereus has been detected and implicated in contaminated foods containing fermented soybeans, numerous outbreaks of food poisoning have been caused by $B$. cereus and it is an important foodborne pathogen with a distribution similar to that of Salmonella, Escherichia coli, and Listeria monocytogenes in food industry [2].

\subsubsection{Bacillus cereus Toxin Genes by PCR Method}

Bacillus cereus toxin genes were determined by using a PCR and well diffusion assay methods. There were 2 steps conducted in PCR and well diffusion assay. The first will use exactly the CRET-RPLA and second PCR reaction testing method. The cell-free culture supernatants of Bacillus cereus isolates were subjected to detect for enterotoxin production by $B$. cereus. Enterotoxin-Reverse Passive Latex sensitized (CRET-RPLA) test kit was used. The results as reported in Fig. 1 showed that 12 of 120 Bacillus cereus isolates gave positive sensitivity (25\%) compared with control enterotoxin by lyophilization and then 2 (BTM8-7 and BTM8-8) of these 12 isolated Bacillus cereus strains produced the highest level of enterotoxin, which may cause diarrhea respectively.

As shown in Fig. 2, 49 of Bacillus cereus isolates, which did not give multiplex PCR positive, showed correlation with RPLA test. So that, all Bacillus cereus isolate strains do not have multiplex PCR positive with 227 bp genes positive control Bacillus cereus $(\mathrm{C}=$ Control Cereus rid Toxin produce) and similar negative control still 134 bp $(\mathrm{L}=$ Internal Control), but also difference showed negative Latex sensitized (CRET-RPLA) test. In general, the emetic type of Bacillus cereus foodborne illness is caused by a small cyclic heat-stable peptide toxin known as cereulide, which causes vomiting and nausea for a few hours after consumption of contaminated food. Though Cambodia is the third world country, Royal Government of Cambodia is also considering to reduce food borne disease and improve public health status by introducing food safety standards and market regulation into food industries [4].

\subsection{Isolating Bacillus Strains from Cambodian Fermented Soybean (SIENG) Samples}

Bacillus subtilis strains are important for seed fermentation because of their enzymatic activities contributing to desirable texture, flavor and $\mathrm{pH}$ development [11]. And it was resistant to heat which showed growth in $70 \mathrm{~g} \cdot \mathrm{dm}^{-3} \mathrm{NaCl}$, nitrate reductase positive reaction [12]. As shown in Table 1, these isolated strains among 120 Bacillus strains, were found only 5 Bacillus strains that have ability to fight against the indicator microorganisms. Furthermore, among 5 samples, only one strain (Bacillus CeM6-2) has shown active zone. Bacillus CeM6-2 strain had the highest level antimicrobial compound of Lactobacillus plantarum ATCC 8014 at $28 \%$ of total zone activity compared to others. One of the main characteristics shared among Bacillus strains is the ability to produce a wide range of antimicrobial compounds active against bacteria. The rank based on per $\mathrm{mm} / \mathrm{mL}$ and percentage of total area of level antimicrobial compound of Lactobacillus plantarum ATCC 8014 showed the trend of all type Bacillus strains.

3.2.1 Identification from Isolated Bacteriocin Producing by Bacillus subtilis Strains

The samples were spread plated and streaked on GSP agar plate to get the pure culture and the morphology of the colony is observed. As a result, colonies were found to be circular and irregular in shape, white to creamish in colour and measured to be 1-3 $\mathrm{mm}$ in size mostly, and the optimum temperature of Bacillus strains in order to grow was between $30-37^{\circ} \mathrm{C}$ [13]. In opposite, in anaerobe production, there 

and Safety of Fermented Soybean (SIENG) Produced in Cambodia

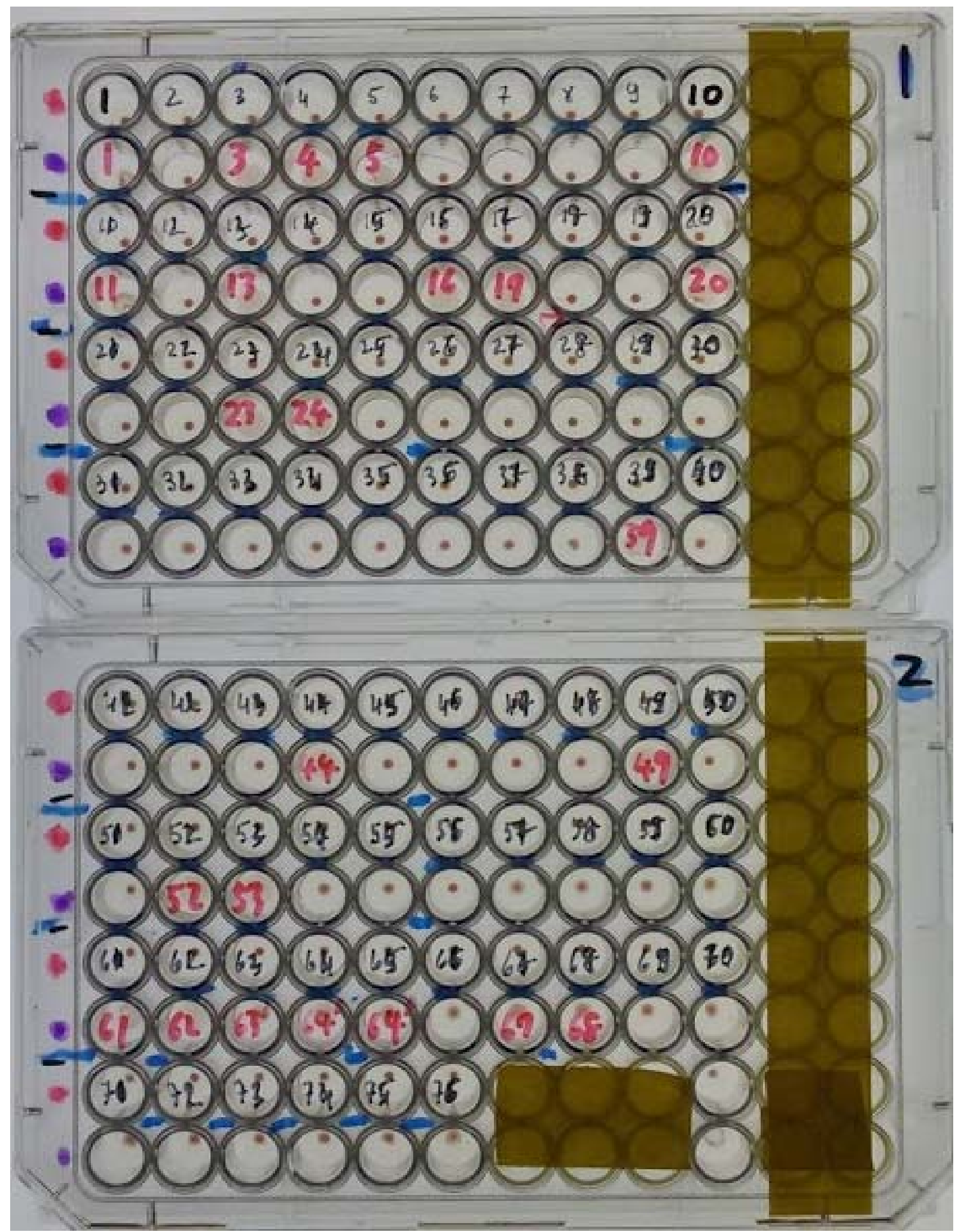

Fig. 1 Bacillus cereus produced enterotoxin by CRET-RPLA method.

Numbers 28 to 76 of Bacillus cereus were isolated from 120 raw SIENG. 

and Safety of Fermented Soybean (SIENG) Produced in Cambodia

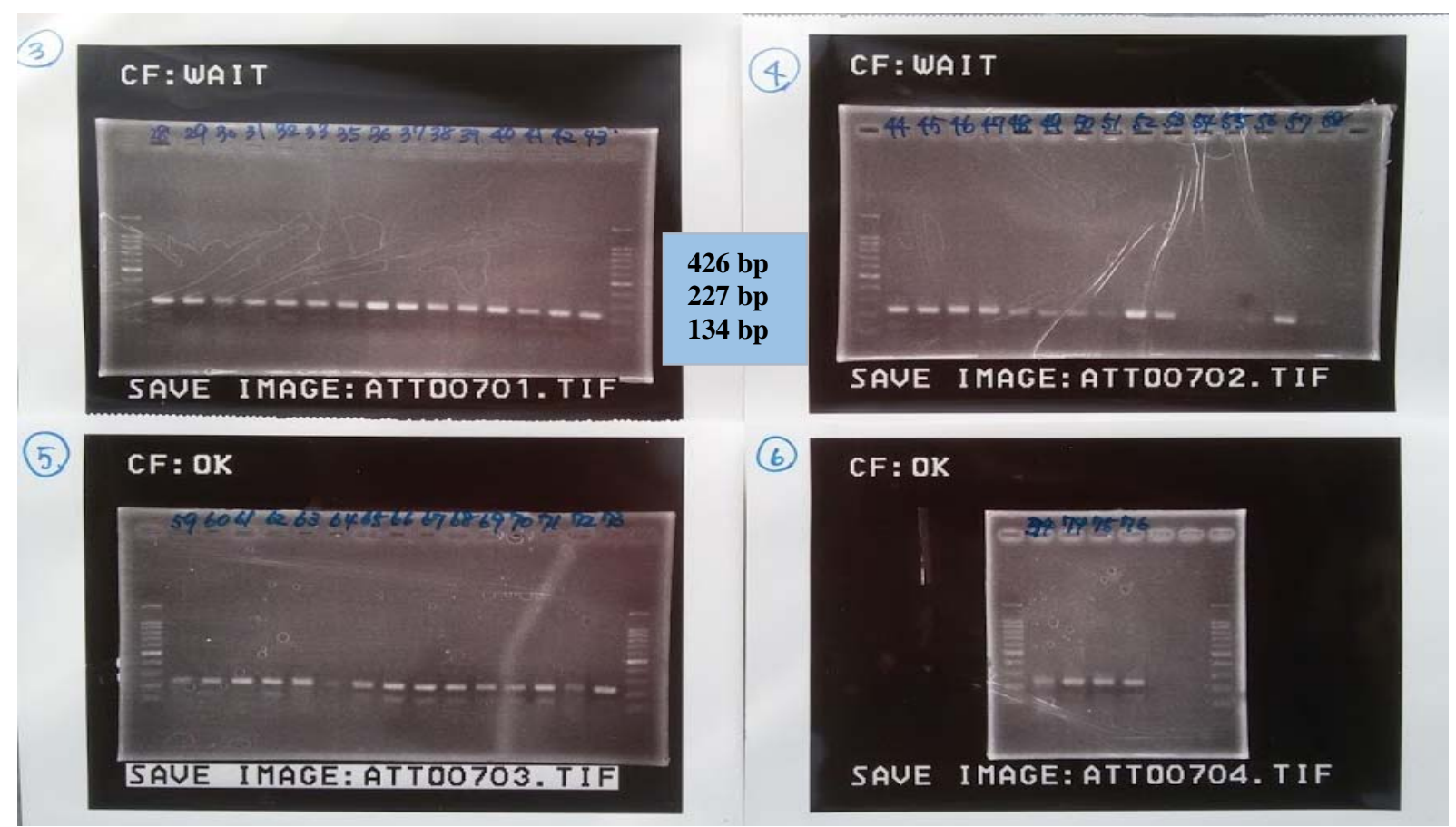

Fig. 2 Bacillus cereus toxin genes by multiplex PCR method.

Table 1 Growth of isolated strains and the zone activities of the isolated strains.

\begin{tabular}{|c|c|c|c|c|c|c|}
\hline \multirow[t]{2}{*}{ No. } & \multirow{2}{*}{ Bacillus strains } & \multirow{2}{*}{ Incubator time } & \multirow{2}{*}{ Incubator temperature } & \multicolumn{3}{|c|}{$\begin{array}{c}\text { Diameter of zone activity }(\mathrm{mm} / \mathrm{mL}) \text { for Lactobacillus } \\
\text { plantarum ATCC } 8014\end{array}$} \\
\hline & & & & Total & Average & Percentage \\
\hline 1 & CeM6-2 & \multirow{6}{*}{ Overnights } & \multirow{6}{*}{$35^{\circ} \mathrm{C}$} & 52.00 & 13.00 & 28.00 \\
\hline 2 & СeM6-8 & & & 48.00 & 12.00 & 26.00 \\
\hline 3 & CeM6-7 & & & 40.00 & 10.00 & 21.00 \\
\hline 4 & BTM8-4 & & & 34.00 & 8.50 & 18.00 \\
\hline 5 & TSM5-9 & & & 14.00 & 3.50 & 7.00 \\
\hline Total & & & & 188.00 & 47.00 & 100.00 \\
\hline
\end{tabular}

Size of well (5 mL) was excluded from calculation of all the samples.

was only one Bacillus strain growing and taking a very longer time for growing but staying for only a short life compared to aerobe production because Bacillus species including Bacillus subtilis can be obligated in both conditions-aerobes (mostly) and anaerobes (rarely and stay in short life) according to the existing publications [7]. Nonetheless, according to another publication [12], a good condition that Bacillus strain can grow well is in aerobes production and its typical characteristics of the Bacillus subtilis are a facultative aerobic, Gram-positive rod, and spore formation. There are three kinds of test for biological counting VPOF test, Manito Salt, and Catalase test. Bacillus species will be positive for the enzyme catalase when there has been oxygen. The result has shown that all Bacillus strains are fermented in $\mathrm{OF}$ test, where only one of BTM8-4 was negative in VP and all positive in VP, Manito Salt and Catalase test, including Bacillus subtilis, and they were catalase-positive reaction, mannitol, and maltose [12].

3.2.2 Subject to Assay of Bacillus subtilis Strains

Five (5) selected strains of Bacillus have been taken to determine antimicrobial activity against indicator organisms and were determined by using a well diffusion assay method. There was a significant difference among the zone activities of Bacillus subtilis strains classifications against indicator organisms of Lactobacillus plantarum bacteria, and they mostly had 

and Safety of Fermented Soybean (SIENG) Produced in Cambodia

activity at $35^{\circ} \mathrm{C}$ much more than at $30{ }^{\circ} \mathrm{C}$.

From the past step, after receiving results of bacteriocin producing Bacillus strains at 17 and 24 hours, those 5 strains were gone for further test to isolate the strongest Bacillus subtilis strain which could produce bacteriocin the best in comparison with other strains. The total diameter of zone activity (mm/mL) for Lactobacilus plantarum and API50 CH was used in the context of "Measure of the Rank and Classify Bacteriocin Productions on the Bacillus subtilis Strain” for final selection of bacteriocin. The categories, rank and selection of bacteriocin production analysis of all types of Bacillus are presented in Table 2.

Table 2 revealed that mean of CeM6-2 strain was $13.50 \mathrm{~mm} / \mathrm{mL}$, 53\%, which was the highest proportion of total area of zone activity for Lactobacilus plantarum linked to other strains that were measured and the following order of Bacillus strain was BTM8-4 (0.75 mm/mL, 3\%), CeM6-8 (1.50 mm/mL, 6\%), TSM5-9 (3.00 mm/mL, 12\%) and CeM6-7 (7.50 $\mathrm{mm} / \mathrm{mL}, 27 \%)$ strains respectively. The rank and selection of Bacillus strain were based on its size $(\mathrm{mm} / \mathrm{mL})$ and percentage of zone activity that showed the trend for all types of Bacillus subtilis strains.

Accordingly, only one strain CeM6-2 which had very strong zone activities was selected for further test since it was able to suppress the growth of Lactobacillus plantarum bacteria, which was in parallel with existing researches stating that, some
Bacillus subtilis have been reported to produce bacteriocins which suppress the growth of Gram positive spoilage and pathogenic bacteria [2, 14]. In addition, we also found that antimicrobial activity against indicator organism of CeM6-2 was more active at $30{ }^{\circ} \mathrm{C}$ compared to $35^{\circ} \mathrm{C}$, overnight. There are also some strains such as CeM6-2 strains which showed antimicrobial activity against indicator organism. However, these strains are half-strong compared to other strains. The strain CeM6-2 was identified as Bacillus subtilis by $96.2 \%$ and a $t$-value at 0.76 homology correspondingly counting on API 50 CH V4.1 (BioMérieux) profiles (not shown) and their physiological characteristics. Finally, only 1 Bacillus strain that had strong activity was selected for the next experiment.

3.2.3 Characterize the Bacteriocin Produced by Isolated Strain

The result obtained from our test showed $B$. CeM6-2 strain had ability resistant to heat. Similarly, $B$. subtilis strains may produce other antimicrobial substances, which have been characterized to a much lesser extent [7].

(1) Incubator Temperature and Timing

In this test, we used two variables of temperature $\left(30{ }^{\circ} \mathrm{C}\right.$ and $\left.37^{\circ} \mathrm{C}\right)$ and different timing $(0 \mathrm{~h}, 6 \mathrm{~h}, 8 \mathrm{~h}$ and $12 \mathrm{~h}$ for first day and $0 \mathrm{~h}, 14 \mathrm{~h}, 16 \mathrm{~h}, 18 \mathrm{~h}, 20 \mathrm{~h}$ and $22 \mathrm{~h}$ for second day), and the Lactobacillus plantarum bacteria were used as the indicator strain. The test was conducted for 2 days.

Table 2 Rank and selection of bacteriocin produced by Bacillus subtilis strain category by total diameter of zone activity (mm/mL) for Lactobacilus plantarum.

\begin{tabular}{|c|c|c|c|c|c|c|c|c|c|c|}
\hline \multirow[t]{2}{*}{ S.N. } & \multirow{2}{*}{$\begin{array}{l}\text { Type of Bacillus } \\
\text { subtilis strains }\end{array}$} & \multirow{2}{*}{$\begin{array}{l}\text { Incubator } \\
\text { time (h) }\end{array}$} & \multirow{2}{*}{$\begin{array}{l}\text { Incubator } \\
\text { temperatur } \\
\text { e }\left({ }^{\circ} \mathrm{C}\right)\end{array}$} & \multirow{2}{*}{$\begin{array}{l}\text { Total No. } \\
\text { zone } \\
\text { activity } \\
(\mathrm{mm} / \mathrm{mL}) \\
\text { at } 35^{\circ} \mathrm{C}\end{array}$} & \multirow{2}{*}{$\begin{array}{l}\text { Incubator } \\
\text { Temperat } \\
\text { ure }\left({ }^{\circ} \mathrm{C}\right)\end{array}$} & \multirow{2}{*}{$\begin{array}{l}\text { Total No. } \\
\text { zone } \\
\text { activity } \\
(\mathrm{mm} / \mathrm{mL}) \\
\text { at } 30^{\circ} \mathrm{C}\end{array}$} & \multirow{2}{*}{$\begin{array}{l}\text { No. } \\
\text { responde } \\
\text { nts of } B \text {. } \\
\text { subtilis } \\
\text { activates }\end{array}$} & \multicolumn{3}{|c|}{$\begin{array}{c}\text { Diameter of zone activity }(\mathrm{mm} / \mathrm{mL}) \text { of } \\
\text { Bacillus subtilis strain for } \\
\text { Lactobacilus plantarum bacteria } \\
\end{array}$} \\
\hline & & & & & & & & Total & Mean & Percentage \\
\hline 1 & СeM6-2 & & & 26 & & 28 & 4 & 54.00 & 13.50 & 53.00 \\
\hline 2 & CeM6-7 & & & 14 & & 14 & 4 & 27.00 & 7.00 & 27.00 \\
\hline 3 & TSM5-9 & Overnight & 35 & 7 & 30 & 5 & 3 & 12.00 & 3.00 & 12.00 \\
\hline 4 & СеM6-8 & & & 6 & & ND & 2 & 6.00 & 1.50 & 6.00 \\
\hline 5 & ВТM8-4 & & & 3 & & ND & 2 & 3.00 & 0.75 & 3.00 \\
\hline & Total & - & - & - & - & - & - & 103 & - & 100.00 \\
\hline
\end{tabular}

ND: not detected. 


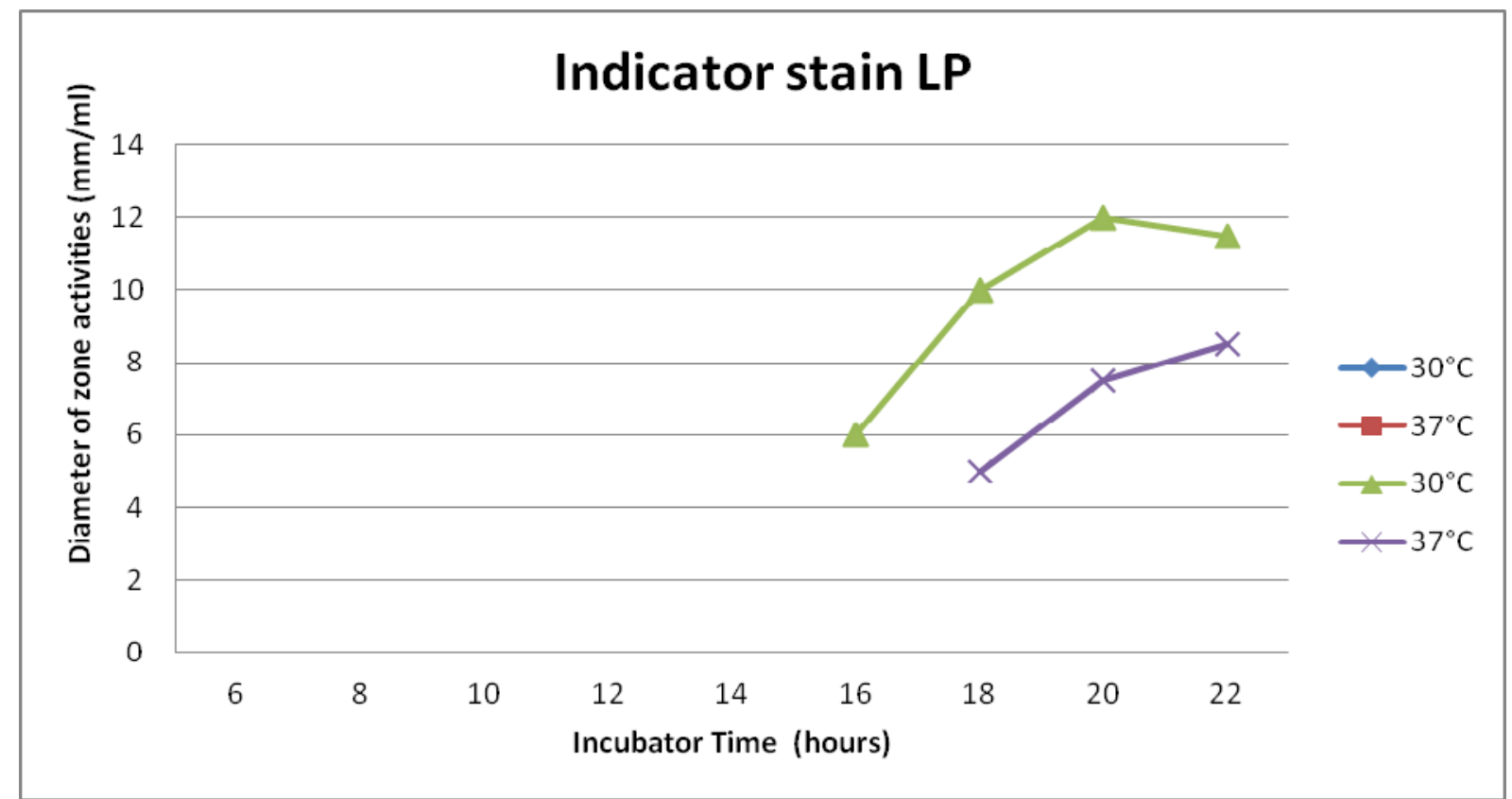

Fig. 3 Effect of difference incubator temperature and timing on the activity of bacteriocin produced by Bacillus CeM6-2 strain.

As seen in Fig. 3, in the first day of test, the antimicrobial activities of bacteriocin had no antimicrobial activities at all timing and temperatures. The antimicrobial activities actively happened in second day of the test. The same figure and table revealed that the antimicrobial activities of bacteriocin started to be active after $16 \mathrm{~h}$ of incubation at $30{ }^{\circ} \mathrm{C}$. The antimicrobial activities kept increasing consistently for four hours, and gradually decreased after $20 \mathrm{~h}$ of incubation at $30{ }^{\circ} \mathrm{C}$. At $37^{\circ} \mathrm{C}$, the bacteriocin started increasing its antimicrobial activities after $18 \mathrm{~h}$ of incubation which was later compared with $30{ }^{\circ} \mathrm{C}$ of incubation temperature. Though, its antimicrobial activity was kept increasing slightly for just only one hour, and started decreasing sharply for the next four hours until became inactivated after $22 \mathrm{~h}$ of incubation at $37{ }^{\circ} \mathrm{C}$. It demonstrated that bacteriocin produced by CeM6-2 strain is more likely to be active at $37^{\circ} \mathrm{C}$ for a longer period compared with its activities at $30{ }^{\circ} \mathrm{C}$ for two tested days. The finding was similar to previous researches that indicated the behavior of bacteriocin towards heat-resistant pathogens also varies [14].

(2) Enzyme Treatment (Indicator Strain LP)
In this test, we used the enzyme contained in $P K$ and $P K-M S F$ as the treatment, and used one type of indicators Lactobacillus plantarum ATCC 8014 (LP). We also used other three of bacteriocin produced by Bacillus subtilis strains including B. CeM6-2PK, B. CeM6-2PK-MSF and B. CeM6-2 untreated, for comparing the result. The effects of heat, nutritional composition and incubation time at $35{ }^{\circ} \mathrm{C}$ and the antibacterial substances were stable within OD, 650 nm of all Bacillas sutilis strains.

Fig. 4 presented the characteristics of antimicrobial activity against $L P$ by Bacillus subtilis strains such as B. CeM6-2PK, B. CeM6-2PK-PMSF (SEING) and B. CeM6-2 untreated, after been cultured in MRS broth contained against LP. It was indicated that, at different timing ( $0 \mathrm{~h}$ to $47 \mathrm{~h}$ ), the result showed that the strain $B$. CeM6-2 untreated and B. CeM6-2PK-PMSF produced the strongest antimicrobial activity against MRS broth contained $L P$ in comparison with $B$. CeM6-2PK, but the other remaining strains $B$. CeM6-2PK were found to have no antimicrobial activity at all. At $0 \mathrm{~h}$, all strains were calculated 0 OD equally. At $0 \mathrm{~h}$ to $47 \mathrm{~h}$, the B. CeM6-2 untreated and B. CeM6-2PK-PMSF were calculated to be $0 \mathrm{OD}$ respectively, which in comparison 


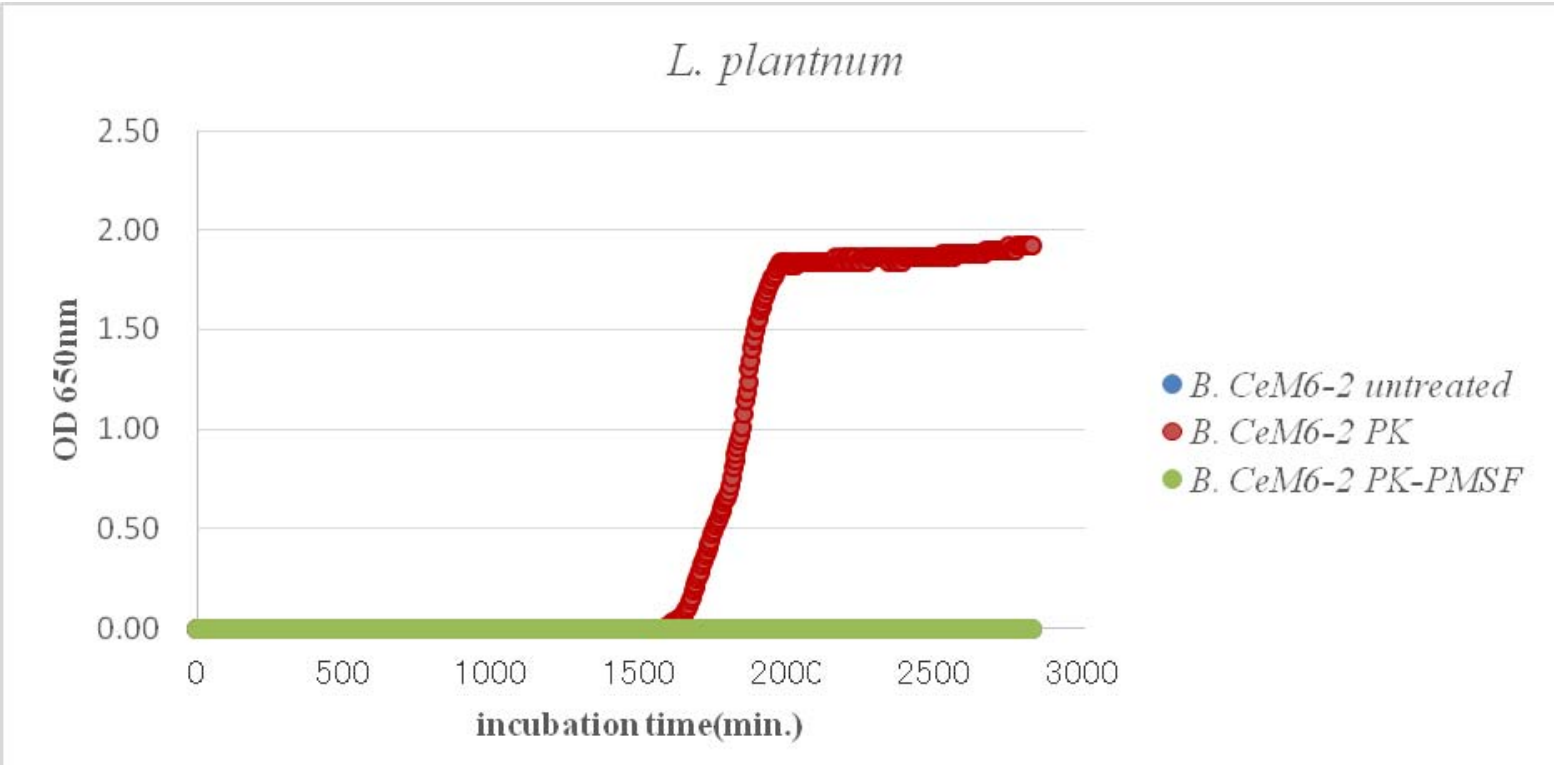

Fig. 4 Enzymes of $P K$ and PK-PMSF resistant for strain B. CeM6-2 compared with B. CeM6-2 untreated strains against indicator $L P$ at different time in MRS broth at $35^{\circ} \mathrm{C}, 47 \mathrm{~h}$.

were less than B. CeM6-2PK that presented at 0.01 $\mathrm{OD}$ to $1.92 \mathrm{OD}$ at $26 \mathrm{~h}$ to $47 \mathrm{~h}$, in correspondingly.

3.2.4 Apply the Bacteriocin to Control the Growth of Gram Positive Pathogenic or Spoilage Bacteria in Foods

Applying bacteriocin to control the growth of Gram positive pathogenic or spoilage bacteria and lactic acid group in foods was conducted against three indicator strains such as Enterococcus faecium, Listeria monocytogenes, Bacillus cereus, Streptococcus pyrogene, Micrococcus luteu and S. aureus (Gram positive pathogenic or spoilage bacteria) and lactic acid group (Lactobacillus brevis, Leuconostoc mesenterides, L. curvatus, Lactobacillus plantnum, Lc. lactis (NinA+) and Lactobacillus lactis) contained B. CeM6-2 comparing with Miyagino strain after culturing in HBI contained against Gram positive; and MRS containing against lactic acid group (OD $=0.1$, $650 \mathrm{~nm}$ ), and volume measurement culture prior to start experiment. Similarity searches with sequences in the bacteriocin produced by Bacillus subtilis strain LFB112 from Chinese herbs, were effective against both Gram-positive and Gram-negative bacteria involved in domestic animal diseases [15].
(1) Gram Positive Group

In order to study the growth controlling of Gram positive pathogenic or spoilage bacteria in foods of antimicrobial compound of the two kinds of $B$. subtilis group B. CeM6-2 (Cambodia) and Miyagino (Japan) growth, the inhibitory activity present in cell-free samples taken at different time intervals was measured. Antibacterial activity could be detected at the mid-log growth phase and quickly extended a maximum at the early inactive phase, subsequently, the antagonistic activity declined.

- Indicator Strain Enterococcus faecium

The control of antimicrobial activity against Enterococcus faecium of two strains B. subtilis and Miyagino after being cultured in BHI broth contained against Enterococcus faecium $(\mathrm{OD}=0.1,650 \mathrm{~nm}$ ) at $35^{\circ} \mathrm{C}$ for $58 \mathrm{~h}$, was discussed in Fig. 5 .

Fig. 5 illustrated that strains B. CeM6-2 did not have antimicrobial activity at $0 \mathrm{~min}$ as its OD is above Miyagino (0.03 compared to $0.02 \mathrm{OD}$ ). The OD of $B$. CeM6-2 started to be extremely lower than Miyagino from $100 \mathrm{~min}$ (0.04 to 0.05 ) to 2,000 $\mathrm{min}$ (0.14 to 0.97 ) which resulted in strong power of antimicrobial activity of B. CeM6-2 against Enterococcus faecium 

and Safety of Fermented Soybean (SIENG) Produced in Cambodia

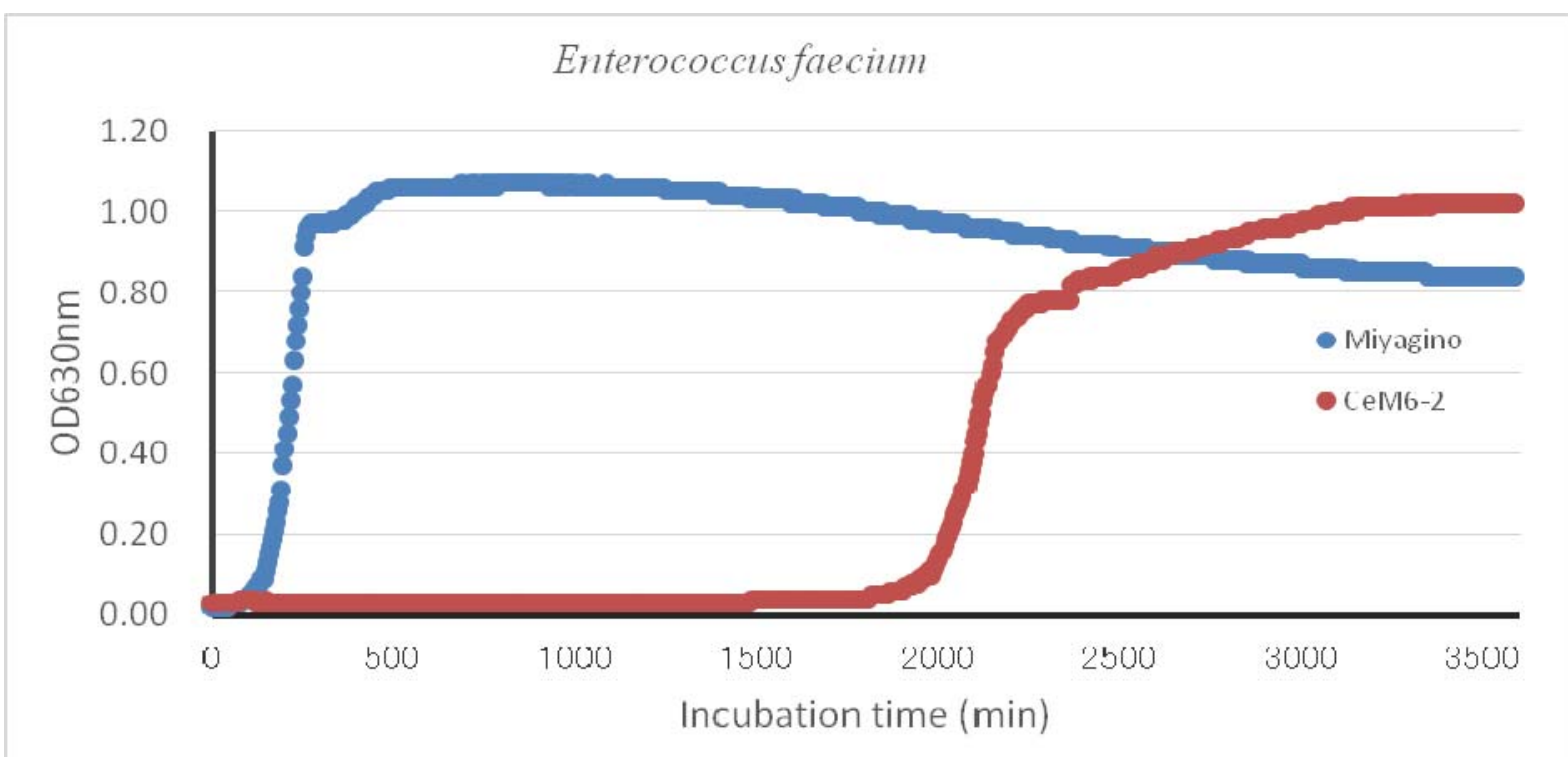

Fig. 5 Effect of bacteriocin produced by Bacillus CeM6-2 strain on the growth of Enterococcus faecium compared with Miyagino at different time in $\mathrm{HBI}$ broth at $35^{\circ} \mathrm{C}$ for $58 \mathrm{~h}$.

compared with Miyagino strain during this timing. From 2,005 to 2,645 $\mathrm{min}$, B. CeM6-2 has less antimicrobial activity comparing to previous timing but its OD is still far lower than Miyagino. From 2,650 to 3,500 min, B. CeM6-2 has 0.90 to 1.02 OD higher than Miyagino that has 0.89 to 0.84 OD which resulted in no inhibition within this specific timing.

- Indicator Strain Listeria monocytogenes

The control of antimicrobial activity against Listeria of two strains B. subtilis and Miyagino after being cultured in BHI broth contained against Listeria $\mathrm{OD}=0.1,650 \mathrm{~nm}$ ) at $35^{\circ} \mathrm{C}$ for $30 \mathrm{~h}$. As seen in Fig. 6, both strains have the same $0.03 \mathrm{OD}$ at $0 \mathrm{~min}$. However, B. CeM6-2 commencing falls at 90 min to 0 OD stably until 3,500 min. Differently, OD of Miyagino is above $B$. CeM6-2 at all entire experiment timing. Miyagino maintains almost stable of OD from 0 min (0.03 OD) to $1,145 \mathrm{~min}$ (0.07 OD) and sharply increases afterward until 1,510 min (1.07 OD). It is gradually reducing later until $3,500 \mathrm{~min}$ to $0.72 \mathrm{OD}$. This result interpreted that $B$. CeM6-2 has a strong antimicrobial activity against Listeria monocytogenes as its amount of OD is lower than Miyagino for entire experiment timing.

- Indicator Strain Bacillus cereus
Fig. 7 indicated that from 0 to 1,310 min, Bacillus CeM6-2 has inhibited against Bacillus cereus compared with Miyagino since its OD is 0.02 to 0.71 comparing to 0.04 to 0.72 . From 1,315 to 2,050 min, Bacillus CeM6-2 slowly fluctuated with above OD amount comparing with Miyagono strain from (0.72 OD to 0.67$)$ to ( 0.71 to $0.66 \mathrm{OD})$ which means that it has no antimicrobial power against Bacillus cereus within this specific timing. At 2,085 min onward, the OD amount of Bacillus CeM6-2 resumed its antimicrobial activity as its OD amount started to decrease below Miyagino from (0.66 to 0.39 OD) comparing to (0.67 to $0.77 \mathrm{OD}$ ). This result concluded that Bacillus CeM6-2 has specific antimicrobial activity against Bacillus cereus within certain timing from 0 to $1,310 \mathrm{~min}$; and from 2,085 to $3,500 \mathrm{~min}$ only.

- Indicator Strain Streptococcus pyrogene

According to Fig. 8, Bacillus CeM6-2 strain has a perfect antimicrobial activity against Streptococcus pyrogene compared with Miyagino as it has stable amount of OD starting from 0 min (0.01 OD) to 3,500 min (0.02 OD). In contract, Miyagino strain has slowly increased amount of OD starting from $0 \mathrm{~min}$ at $0.04 \mathrm{OD}$ to $1,255 \mathrm{~min}$ at $0.08 \mathrm{OD}$ and it sharply increased 

and Safety of Fermented Soybean (SIENG) Produced in Cambodia

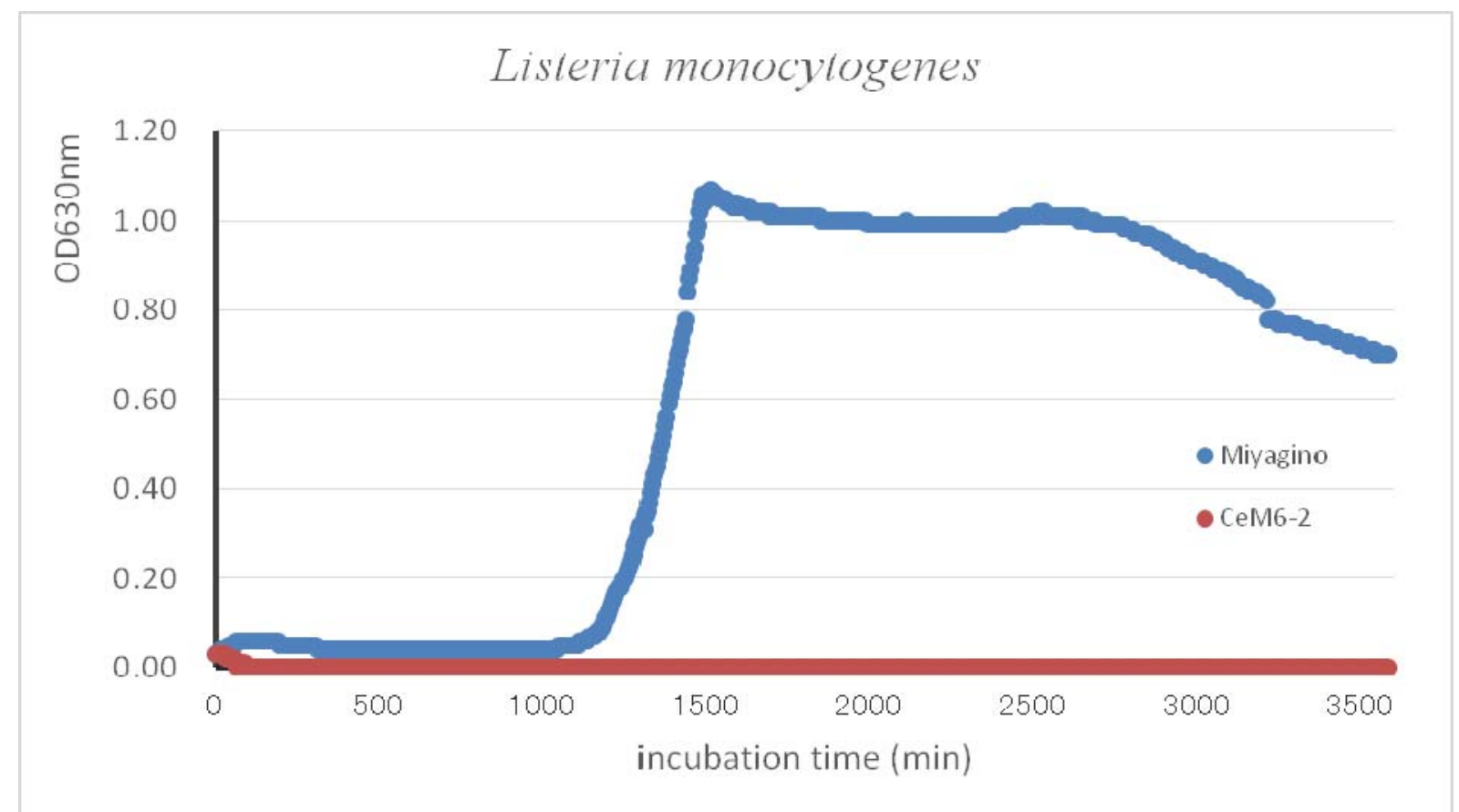

Fig. 6 Effect of bacteriocin produced by Bacillus CeM6-7 strain on the growth of Listeria monocytogenes compared with Miyagino at different time in $\mathrm{BHI}$ broth at $35^{\circ} \mathrm{C}$ for $58 \mathrm{~h}$.

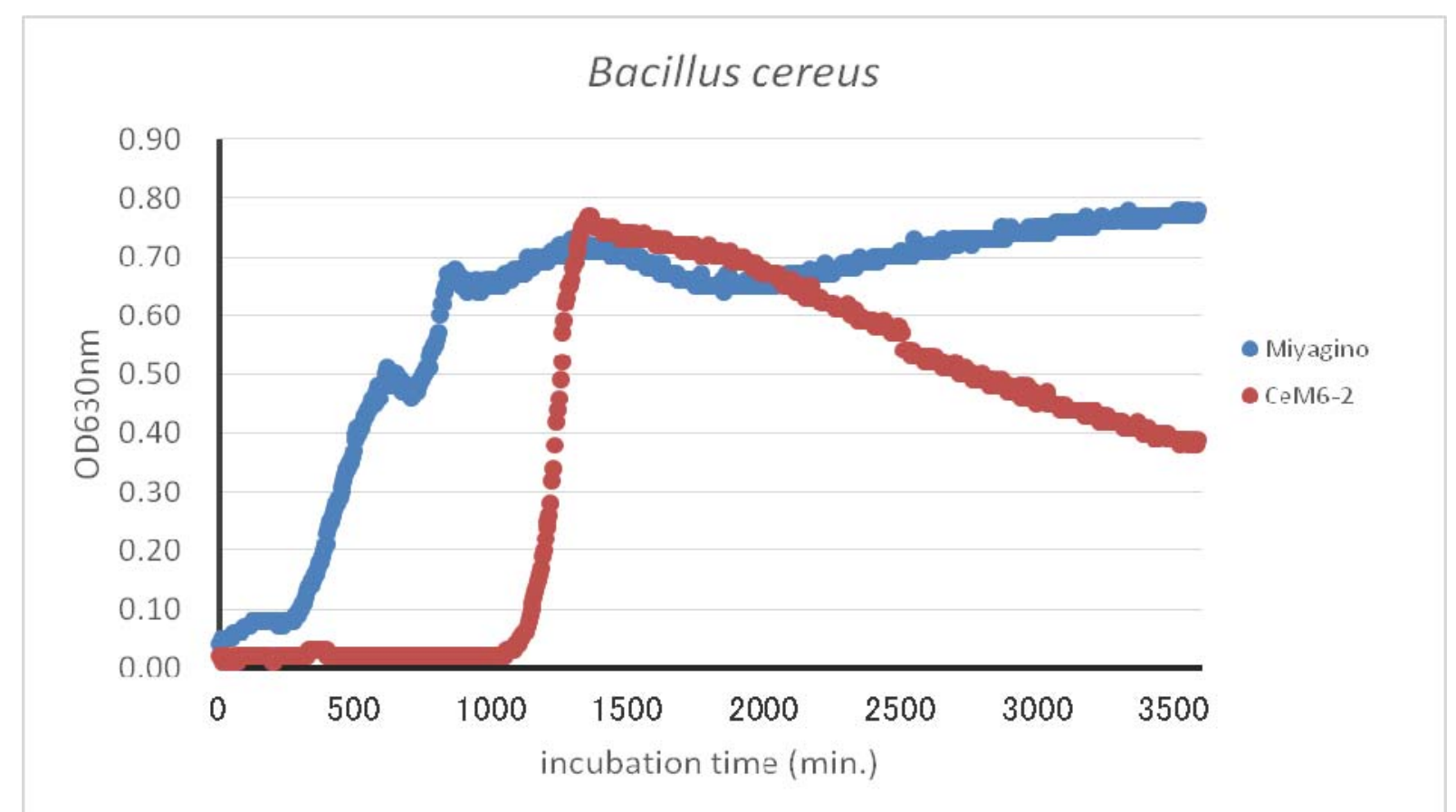

Fig. 7 Effect of bacteriocin produced by Bacillus CeM6-2 strain on the growth of Bacillus cereus compared with Miyagino at different time in BHI broth at $35^{\circ} \mathrm{C}$ for $58 \mathrm{~h}$. 

and Safety of Fermented Soybean (SIENG) Produced in Cambodia

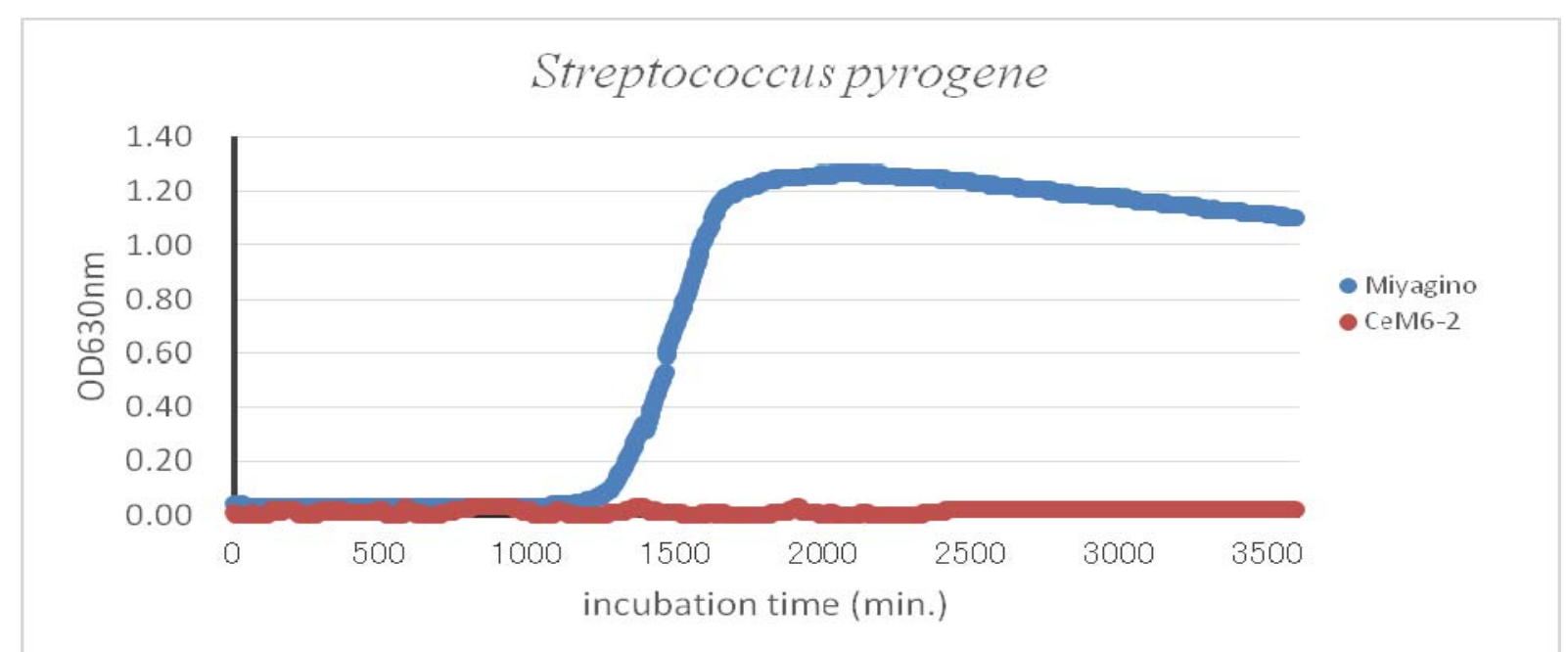

Fig. 8 Effect of bacteriocin produced by Bacillus CeM6-2 strain on the growth of Streptococcus pyrogene compared with Miyagino at different time in BHI broth at $35^{\circ} \mathrm{C}$ for $58 \mathrm{~h}$.

afterward to 3,500 $\mathrm{min}$ at $0.78 \mathrm{OD}$.

- Indicator Strain Micrococcus luteus

Fig. 9 indicated that both strains, Miyagino and Bacillus CeM6-2 strains, have same amount of OD starting from 0 to $35 \mathrm{~min}$ at $0.03 \mathrm{OD}$. From 40 to 575 min, B. CeM6-2 has higher amount of OD compared with Miyagino; 0.03 and 0.02 OD comparing to 0.02 and $0.01 \mathrm{OD}$ of Miyagino strain. In 580 to 1,925 min, B. CeM6-2 and Miyagino have same amount of OD (0.02). In 1,935 to 2,465 min OD of B. CeM6-2 and Miyagino are in stable amount (0.02 OD) and (0.01 OD). From 2,470 to $3,500 \mathrm{~min}$, both strains have the same amount of OD, 0.02 equally. This can be concluded that B. CeM6-2 strain has no antimicrobial activity against Micrococcus luteus.

- Indicator Strain S. aureus

Fig. 10 showed the result of comparison on effect of bacteriocin produced by Bacillus CeM6-2 strain on the growth of Staphylococcus aureus comparing to Miyagino at different time in BHI broth at $35{ }^{\circ} \mathrm{C}$ for $41 \mathrm{~h}$. In according with the same figure, in 0 to 2,500 min, strain Bacillus CeM6-2 has suddenly increased OD amount from 0.04 to 1.46 OD higher than Miyagino strain which is increasing from 0.04 OD to 0.83 OD. Consequently, the result demonstrated there is no antimicrobial activity of B. CeM6-2 strains against Staphylococcus aureus.

In short, the Bacillus CeM6-2 strain performed well when treated with Gram positive group; especially it has strong antimicrobial activity against Listeria monocytogenes, and Streptococcus pyrogene. Following from this, Bacillus CeM6-2 has partially antimicrobial activity, during specific timing, against Bacillus cereus ( 0 to $1,310 \mathrm{~min}$ and 2,085 to 3,500 $\mathrm{min}$ ), and Enterococcus faecium (100 to 2,000 min and 2,005 to 2,645 min), but it was found to have no power to suppress against Micrococcus luteus and Staphylococcus aureus. This result was in parallel with existing researches stating that, some Bacillus subtilis have been reported to produce bacteriocins which suppress the growth of Gram positive spoilage and pathogenic bacteria [2, 14].

(2) Lactic Acid Groups

In this test, we used two variables of temperature $35{ }^{\circ} \mathrm{C}$ and incubator timing $40 \mathrm{~h}$, and one kind of antibacterial produced by B. CeM6-2 (Cambodia) of the tested strains compared with Miyagino strain after being cultured in MRS containing against lactic acid group (Lactobacillus brevis, Leuconostoc mesenterides, L. curvatus, Lactobacillus plantnum, Lc. Lactis (NinA+) and Lactobacillus lactis with OD $=0.1$, $650 \mathrm{~nm}$ ), bacteria were used as the indicator strain. 

and Safety of Fermented Soybean (SIENG) Produced in Cambodia

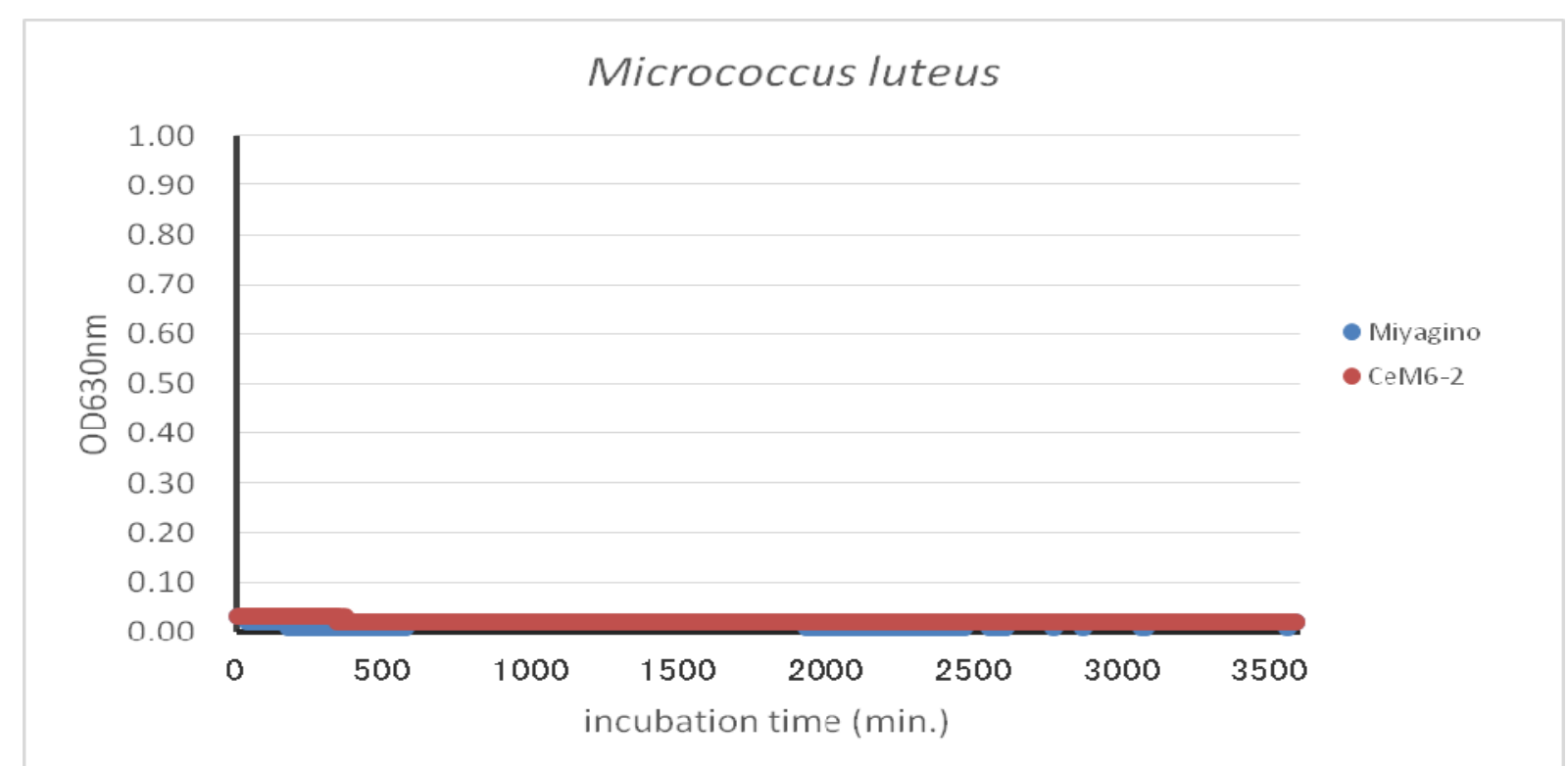

Fig. 9 Effect of bacteriocin produced by Bacillus CeM6-2 strain on the growth of Micrococcus luteus compared with Miyagino at different time in BHI broth at $35^{\circ} \mathrm{C}$ for $58 \mathrm{~h}$.

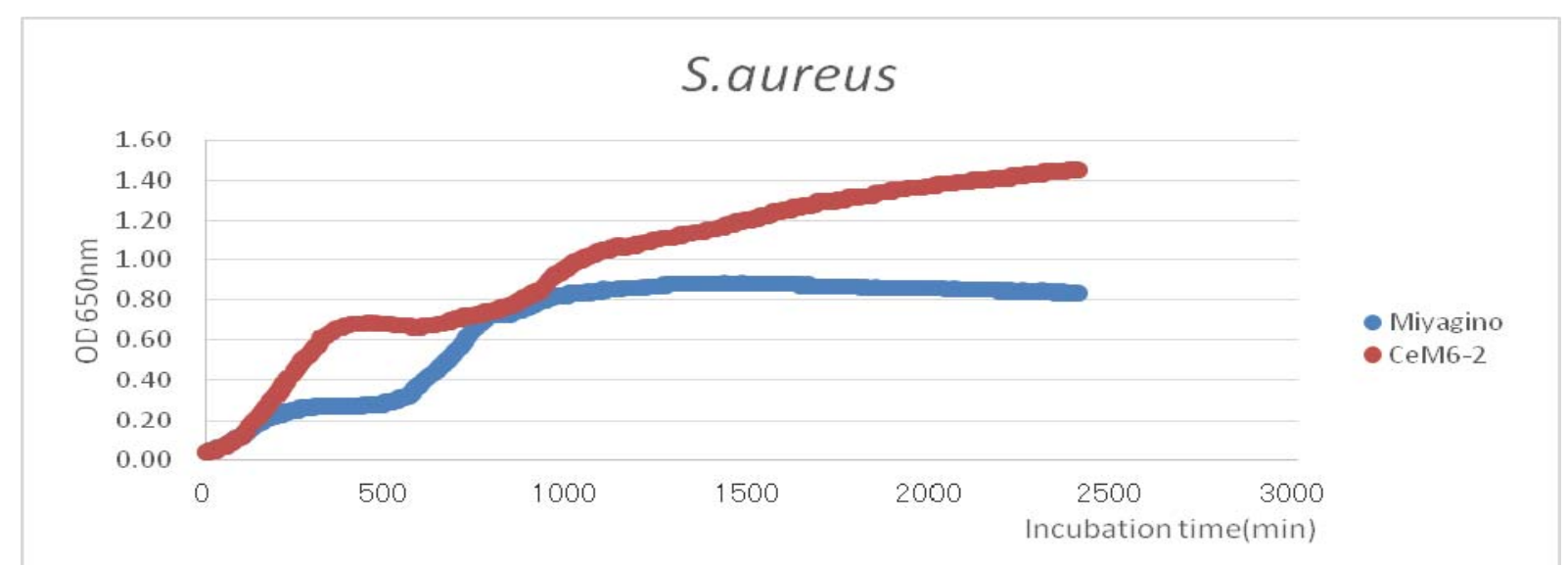

Fig. 10 Effect of bacteriocin produced by Bacillus CeM6-2 strain on the growth of Staphylococcus aureus compared to Miyagino at different time in BHI broth at $35^{\circ} \mathrm{C}$ for $41 \mathrm{~h}$.

However, the test was conducted to measure $\mathrm{pH}$ value of each indicator of bacteriocin produced by Bacillus subtilis strains culture prior to starting experiment and the effects of heat, $\mathrm{pH}$, nutritional composition and incubation time at $35{ }^{\circ} \mathrm{C}$ and the antibacterial substances were stable within OD, 650 $\mathrm{nm}$ and wide range $\mathrm{pH}$ value from 3.858 to 3.923 as shown by the isolates strain against on inhibitory by the bacteriocin produced by B. CeM6-2 strains compared with Miyagino strain to be using control strain. In the cell-free samples taken at different time intervals were measured. Antibacterial activity could be detected at the mid-log growth phase and quickly extended a maximum at the early inactive phase, subsequently, the antagonistic activity declined.

- Indicator Strain L. brevis

Fig. 11 expressed the strong antimicrobial activity of B. CeM6-2 strain against L. brevis compared with Miyagino starting from $0 \mathrm{~min}(0.04 \mathrm{OD})$ to $1,605 \mathrm{~min}$ (0.09 OD). It continued its antimicrobial activity afterward until 2,065 $\mathrm{min}$ (0.93 OD). In 2,070 to 2,500 $\mathrm{min}$ (0.97 OD to $1.62 \mathrm{OD}$ ), its power was reduced and not suppressed against $L$. brevis if 


\section{Application of Antimicrobial Bacillus subtilis Strain as a Starter Culture to Improve Qualities and Safety of Fermented Soybean (SIENG) Produced in Cambodia}

compared with Miyagino (0.96 OD to 0.97 OD). Consequently, B. CeM6-2 has strong power to fight against $L$. brevis starting from 0 to 1,605 min only.

- Indicator Strain Leuconostoc mesenterids

The comparison of effect of bacteriocin produced by $B$. CeM6-7 strain on the growth of Leuconostoc mesenterids compared with Miyagino was argued in Fig. 12. In 0 to $50 \mathrm{~min}$, the OD amount of B. CeM6-2 is between 0.05 to $0.07 \mathrm{OD}$ which is higher than Miyagino 0.04 to 0.07 OD. From 55 to $2,400 \mathrm{~min}$, OD of $B$. CeM6-2 starts falling down from 0.07 to 1.60 lower than Miyagino stated at 0.08 to 1.84 OD.

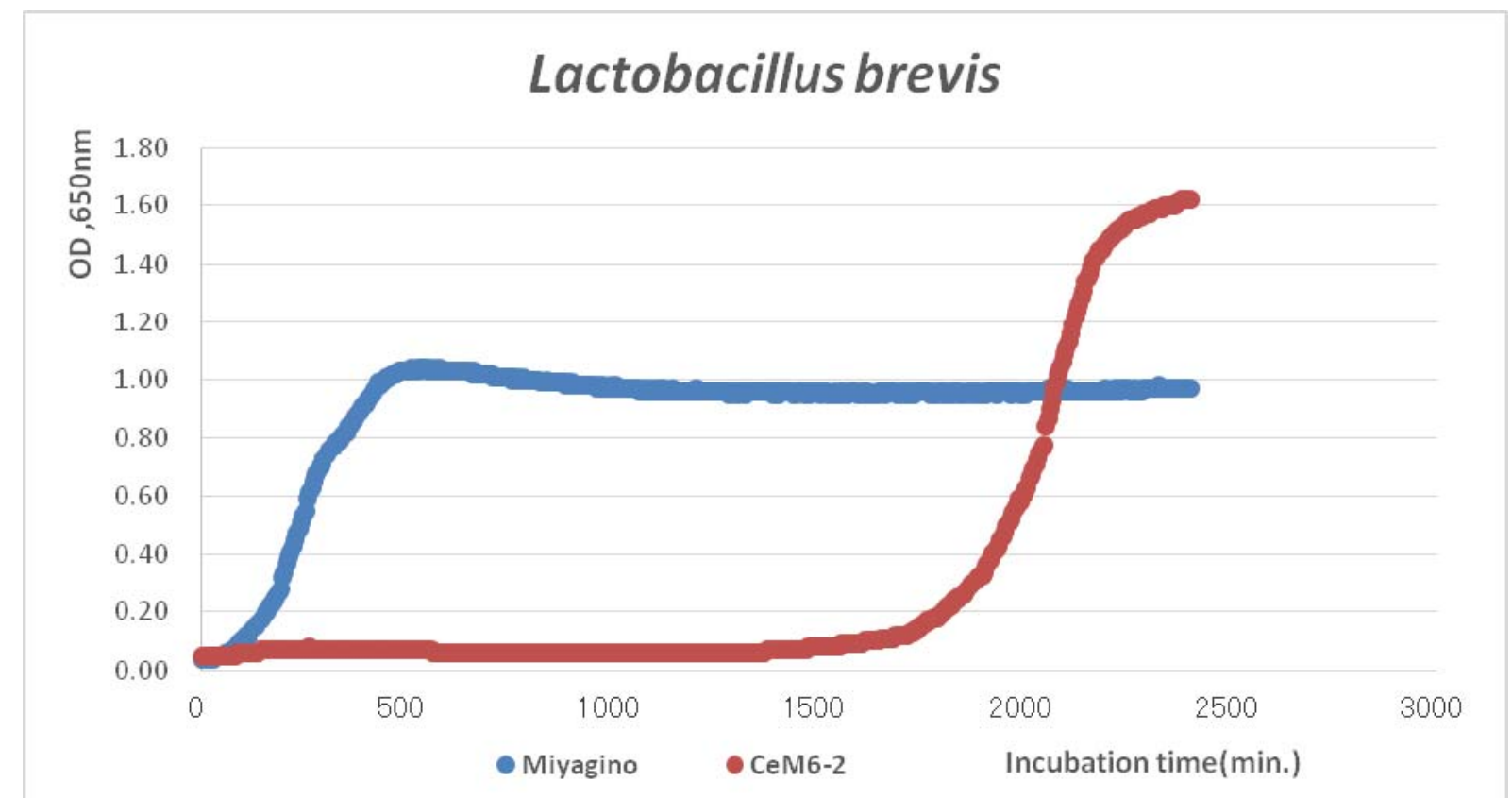

Fig. 11 Effect of bacteriocin produced by B. CeM6-2 strain on the growth of L. brevis compared with Miyagino at different time in MRS broth at $35^{\circ} \mathrm{C}$ for $40 \mathrm{~h}$.

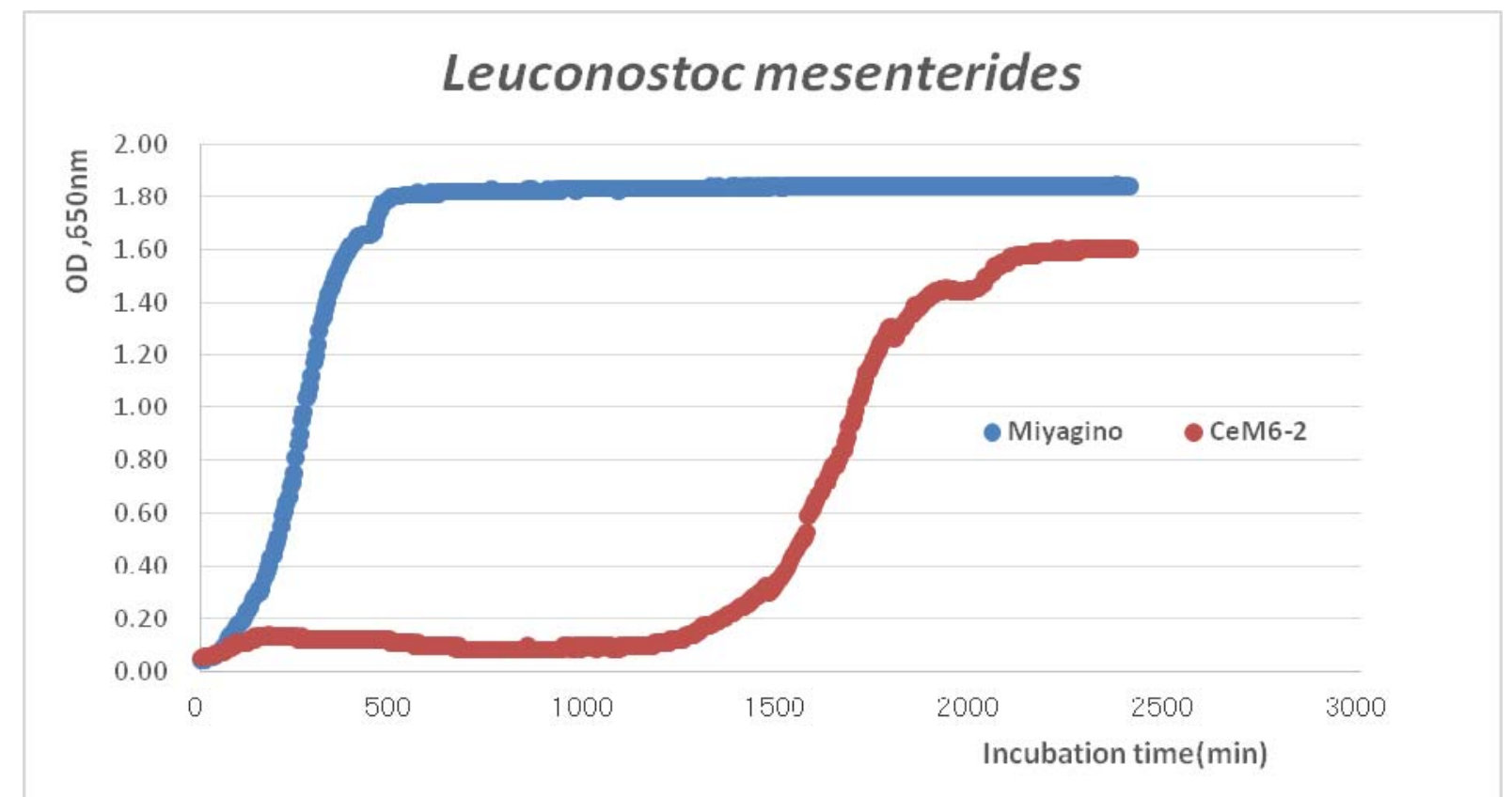

Fig. 12 Effect of bacteriocin produced by B. CeM6-2 strain on the growth of Leuconostoc mesenterids compared with Miyagino at different time in MRS broth at $35^{\circ} \mathrm{C}$ for $40 \mathrm{~h}$. 
This result can be summarized that from the beginning to $50 \mathrm{~min}$, there is absence of antimicrobial activity of B. CeM6-2 against Leuconostoc mesenterids. The presence of antimicrobial activity has started from 55 to 2,400 min.

- Indicator Strain L. curvatus

Fig. 13 discussed on the effect of bacteriocin produced by $B$. CeM6-2 strain on the growth of $L$. curvatus compared with Miyagino. The result indicated that from 0 to $895 \mathrm{~min}, B$. CeM6-2 has OD between 0.06 and 0.10 OD lower than Miyagino 0.06 to 0.11 OD which showed the presence of antimicrobial activity in this period of time. From 905 to 2,400 min the amount of OD of B. CeM6-2 sharply increased from 0.12 and 1.94 OD, higher than Miyagino presented between 0.11 to 1.94 OD which indicated no antimicrobial activity from $905 \mathrm{~min}$ to the end of experiment timing.

In brief, the effect of bacteriocin produced by $B$. CeM6-2 strain on the growth of $L$. curvatus inhibited during minute 0 to 895 only.

- Indicator Strain L. plantarum

Fig. 14 demonstrated that B. CeM6-2 strain has a very strong antimicrobial activity against $L$. plantarum compared with Miyagino. From 0 to 2,500 min OD of B. CeM6-2 decreased from 0.06 to $0.03 \mathrm{OD}$, lower than Miyagino that increased from 0.06 to $2.00 \mathrm{OD}$ within same period of time.

- Indicator Strain Lactococcus lactis subsp. lactis (Produce Nisin A)

The discussion of effect of bacteriocin produced by Bacillus CeM6-2 strain on the growth of Lactococcus lactis subsp. lactis (produce Nisin A) was presented in Fig. 15. From the experiment result, the OD of Bacillus CeM6-7 increased higher than Miyagino strain over the period of time from the beginning of experiment till the end. In 0 to 355 min the OD amount of both strains dramatically increased. OD of Bacillus CeM6-2 presented at 0.03 to 1.54 much more than Miyagino that stood between 0.02 and 1.46 OD. From 360 to 2,400 min the OD amount of both strains is in slow increasing level. OD of Bacillus CeM6-2 stood at 1.55 to 1.76 while the Miyagino stated at 1.47 to 1.67 OD. From the finding above we can conclude that Bacillus CeM6-2 strain has no power to fight against Lactococcus lactis subsp. lactis (produce Nisin A) comparing to Miyagino.

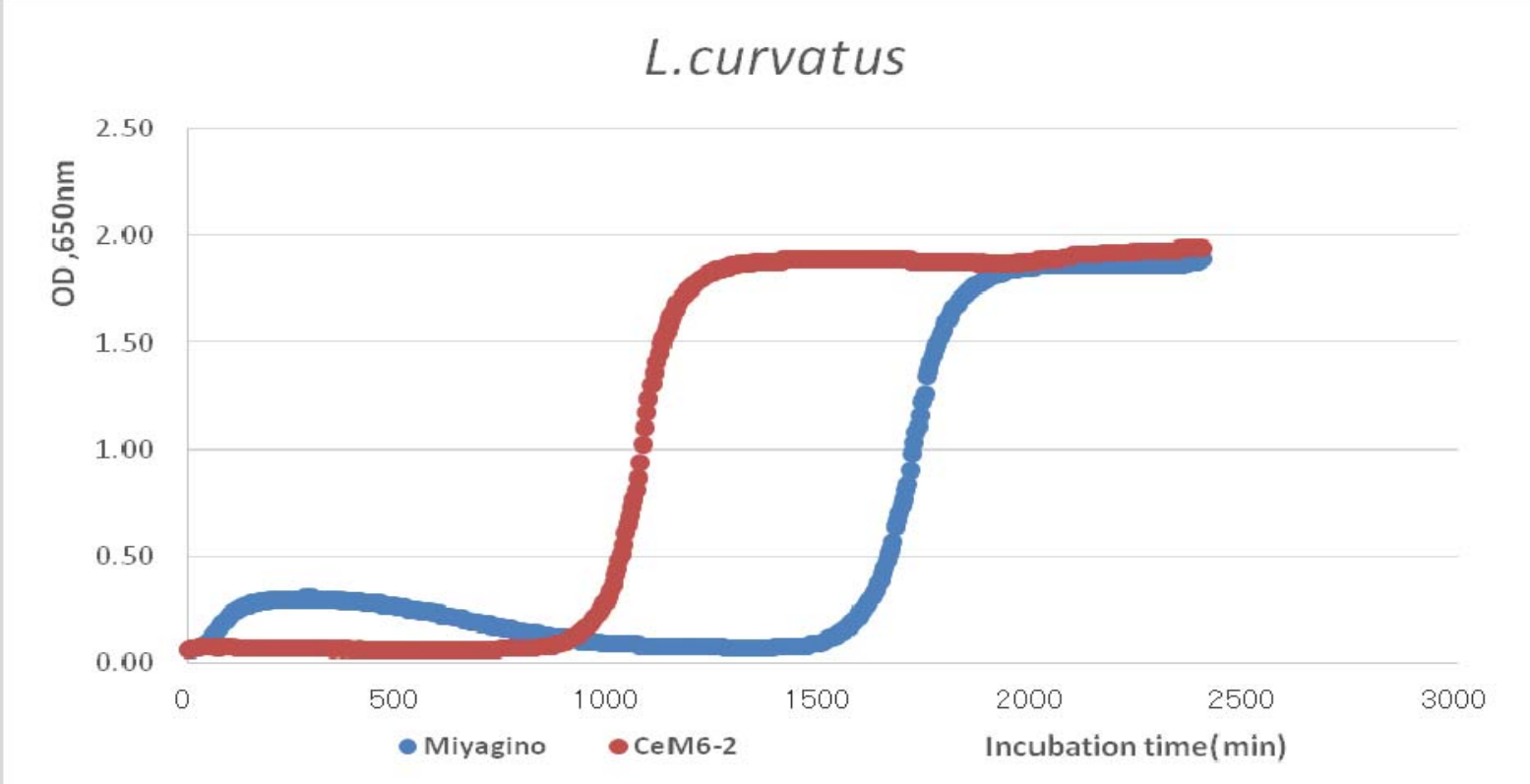

Fig. 13 Effect of bacteriocin produced by B. CeM6-2 strain on the growth of L. curvatus compared with Miyagino at different time in MRS broth at $35^{\circ} \mathrm{C}$ for $40 \mathrm{~h}$. 
Application of Antimicrobial Bacillus subtilis Strain as a Starter Culture to Improve Qualities and Safety of Fermented Soybean (SIENG) Produced in Cambodia

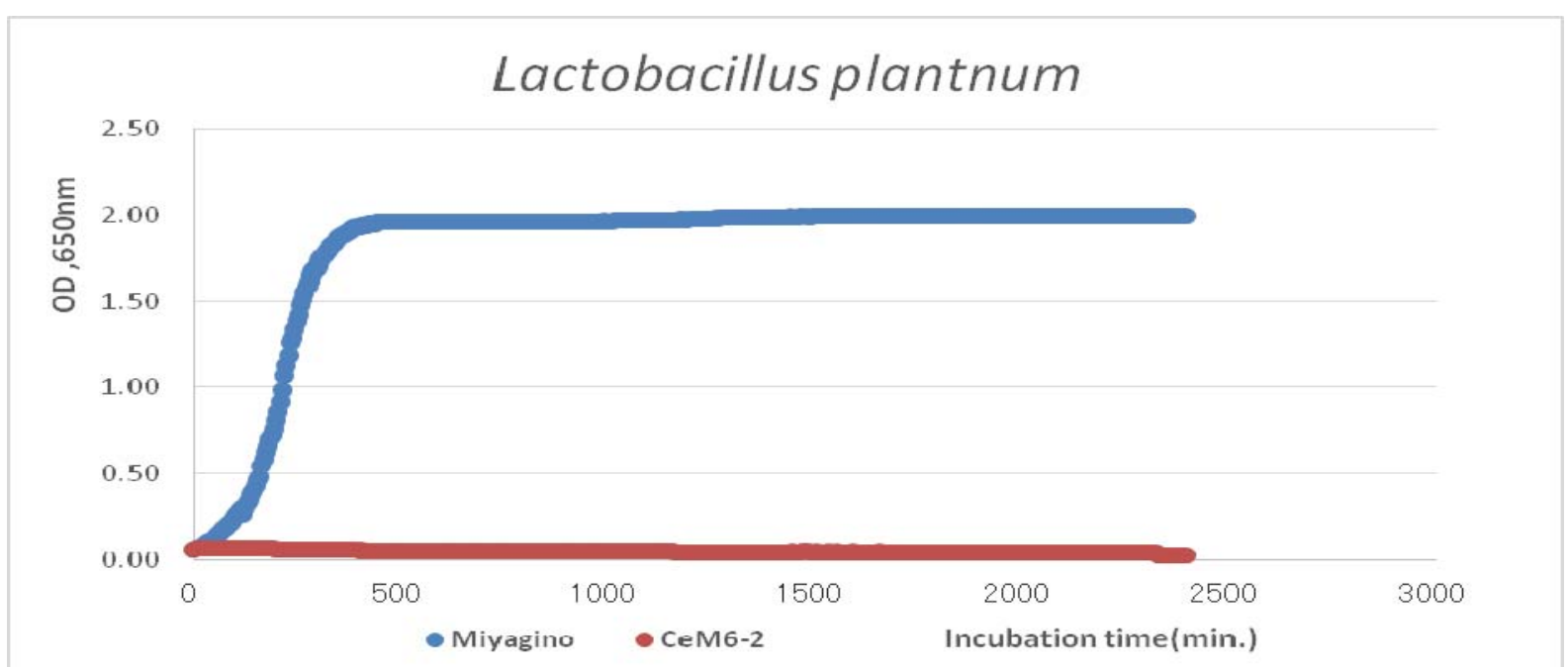

Fig. 14 Effect of bacteriocin produced by B. CeM6-2 strain on the growth of L. plantarum compared with Miyagino at different time in MRS broth at $35^{\circ} \mathrm{C}$ for $40 \mathrm{~h}$.

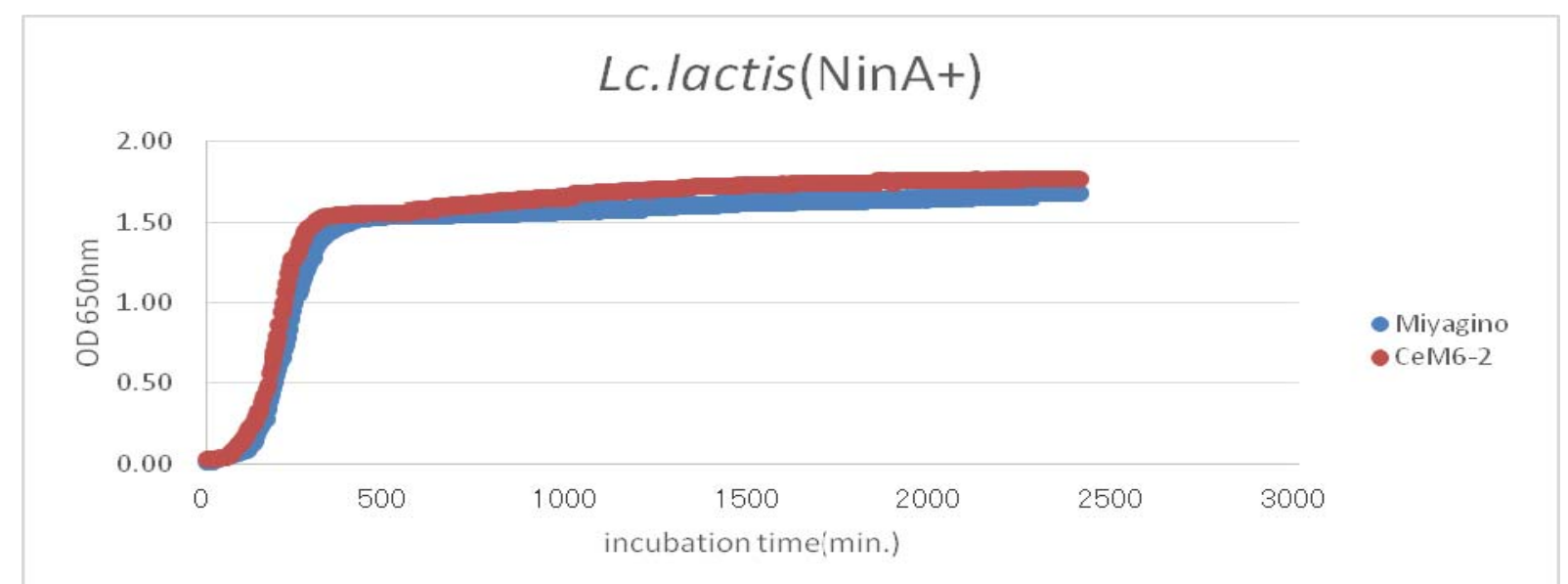

Fig. 15 Effect of bacteriocin produced by Bacillus CeM6-2 strain on the growth of Lactococcus lactis subsp. lactis (produce Nisin A) compared with Miyagino at different time in MRS broth at $35^{\circ} \mathrm{C}$ for $40 \mathrm{~h}$.

- Indicator Strain Lb. lactis

Fig. 16 described finding of effect of bacteriocin produced by $B$. CeM6-2 strain on the growth of $L b$. lactis compared with Miyagino strains. At starting point, 0 to $40 \mathrm{~min}$, the OD of $B$. CeM6-2 stood stably at $0.04 \mathrm{OD}$ higher than Miyagino that presented at 0.03 OD. From 45 to $65 \mathrm{~min}$, OD of both strains stated 0.05 equally. From 70 to $1,080 \mathrm{~min}$ both strains increased amount of OD dramatically; B. CeM6-2 was observed with 0.05 to 1.59 OD lower than Miyagino observed with 0.06 to 1.60 OD. However, from 1090 to $3,500 \mathrm{~min}$, OD of $B$. CeM6-2 rose slowly above Miyagino starting from 1.60 to $1.63 \mathrm{OD}$ which is over
Miyagino starting from 1.59 to 1.62 OD.

In brief, strain B. CeM6-2 showed antimicrobial activity against $L b$. lactis at a specific timing from 70 to $1080 \mathrm{~min}$ only. From all above results, Bacillus CeM6-2 strain performed well when treated with lactic acid group. It demonstrated very strong inhibitation against Leuconostoc mesenterids and L. plantarum for entire experiment timing, but it partially showed high ability to fight against $L$. brevis only during 0 to 1,605 min, L. curvatus from 0 to $895 \mathrm{~min}$, and Lb. lactis from 70 to 1,080 min. Nevertheless, Bacillus CeM6-2 is not inhibited against Lactococcus lactis subsp. lactis (produce Nisin A) in the whole experiment timing. 

and Safety of Fermented Soybean (SIENG) Produced in Cambodia

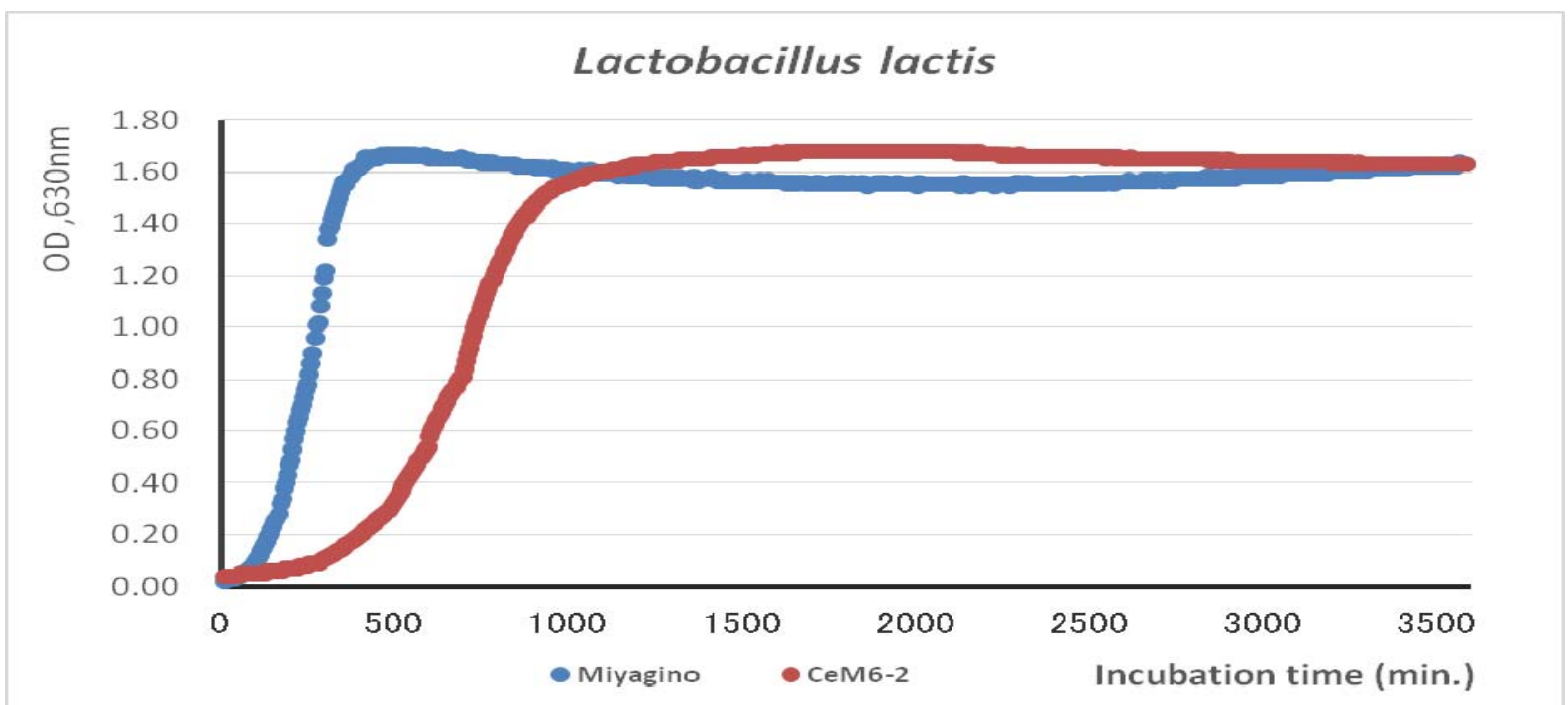

Fig. 16 Effect of bacteriocin produced by B. CeM6-2 strain on the growth of Lb. lactis compared with Miyagino strains at different time in MRS broth at $35{ }^{\circ} \mathrm{C}$ for $40 \mathrm{~h}$.

Thus, this property of bacteriocins produced by $B$. CeM6-2 strain can be used as additive in food processing industries to avoid food spoilage even in $35^{\circ} \mathrm{C}$ temperatures and longer time. Many researches on Bacillus bacteriocins are becoming more intensive and important due to their inhibition activity, which may include Gram-negative bacteria, yeasts or fungi, in addition to Gram-positive species, some of which are known to be pathogenic to humans and animal [15].

3.3 Co-cultivate Bacillus cereus and Bacillus subtilis in a Tripticase Soy Broth or Soybean and Check the Suppression of the Growth of Bacillus cereus

In this test, we used the tripticase soy broth (TSB) as the treatment, and used one type of indicator Bacillus cereus. We also used bacteriocin produced by Bacillus subtilis (B. CeM6-2) strains and different timing from $0 \mathrm{~h}, 24 \mathrm{~h}, 34 \mathrm{~h}$ and $44 \mathrm{~h}$ (first day and $0 \mathrm{~h}$, $24 \mathrm{~h}$, and $34 \mathrm{~h}$ and $44 \mathrm{~h}$ for second day). The test was conducted for 2 days.

Fig. 17 presented the characteristics of antimicrobial activity against $B$. cereus by $B$. subtilis strains such as B. CeM6-2 (isolated from traditional fermented soybean (SEING)) after being cultured in Bacilli's. CeM6-2-TSB contained is against B. cereus
$(\mathrm{OD}=0.1)$. The result showed that the concentration strain B. CeM6-2 (1\%) produced the strongest antimicrobial activity against Bacillus CeM6-2-TSB contained concentration against $B$. cereus compared with all different concentrations strain $B$. subtillis (0.1\%, $0.2 \%, 0.3 \%, 0.4 \%$ and $0.5 \%)$ and indicator strain B. cereus non-contained against Bacilli's. CeM6-2, but the other remaining strains $B$. subtillis $(0.1 \%, 0.2 \%, 0.3 \%, 0.4 \%$ and $0.5 \%)$, was found to have similar antimicrobial activity with $B$. cereus at all different timing. At $0 \mathrm{~h}$, all strains were counted to be $6.00 \log \mathrm{CFU} / \mathrm{mL}$ equally. At $24 \mathrm{~h}, 34 \mathrm{~h}$ and $44 \mathrm{~h}$, the concentration strain B. CeM6-2 (1\%) was calculated to be $8.21 \log \mathrm{CFU} / \mathrm{mL}, 8.16 \log \mathrm{CFU} / \mathrm{mL}$ and $8.14 \log \mathrm{CFU} / \mathrm{mL}$ respectively which in comparison were less than all different concentrations strain B. subtillis $(0.1 \%, 0.2 \%, 0.3 \%, 0.4 \%$ and $0.5 \%)$ that presented at $9.49 \log \mathrm{CFU} / \mathrm{mL}, 9.27 \log \mathrm{CFU} / \mathrm{mL}$ and $8.72 \log \mathrm{CFU} / \mathrm{mL}$ and indicator strain B. cereus non-contained against Bacilli's. CeM6-2, which presented at $12.26 \log \mathrm{CFU} / \mathrm{mL}, 9.67 \log \mathrm{CFU} / \mathrm{mL}$ and $\quad 11.03 \log \mathrm{CFU} / \mathrm{mL}$ correspondingly. Concentration strains B. CeM6-2 (1\%) were found to have high significant protection from Bacilli's. CeM6-2-TSB contained is against B. cereus (OD = 0.1 ). Basically, to control B. cereus and other foodborne 


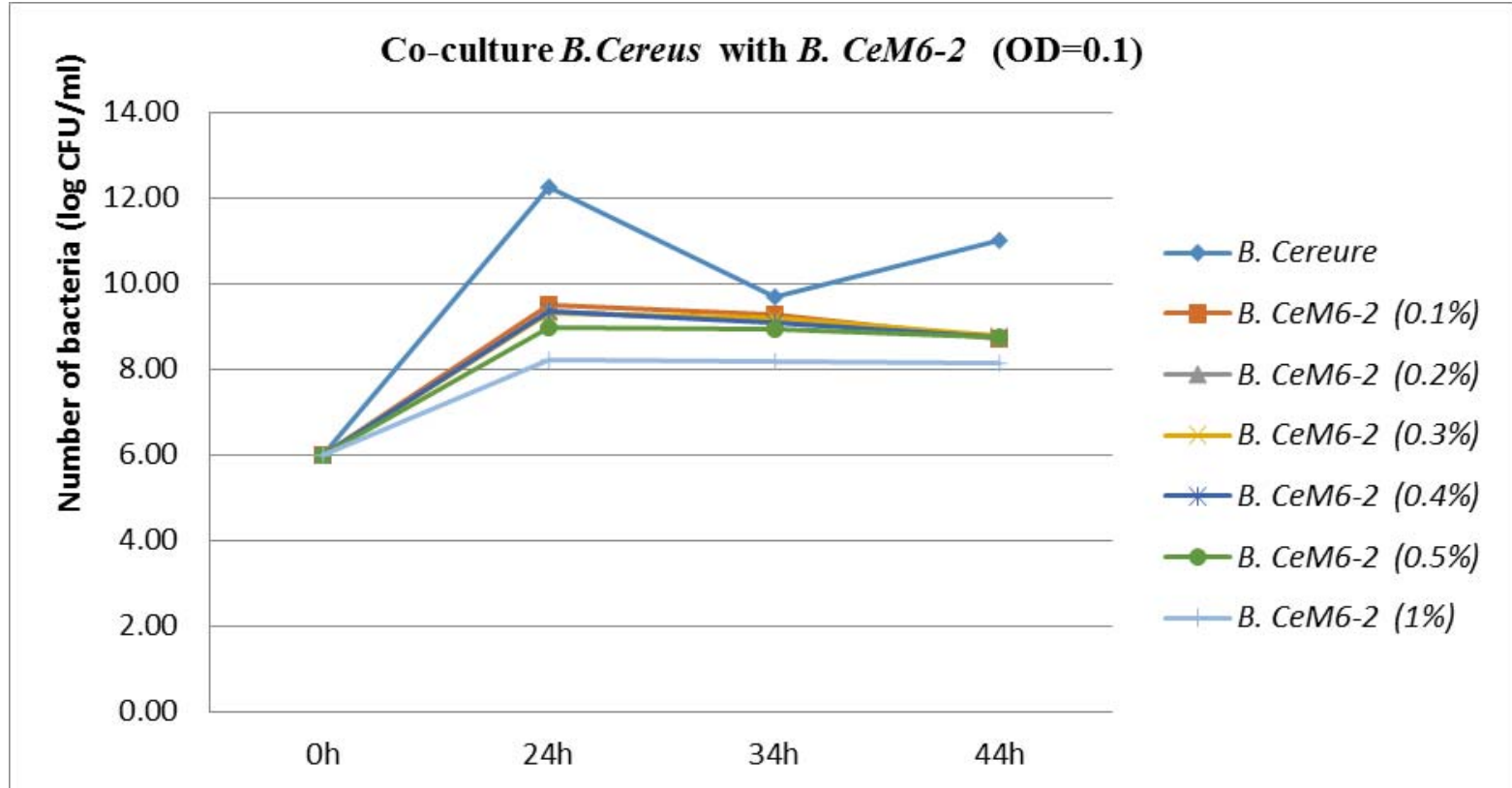

Fig. 17 Effect of bacteriocin produced by B. CeM6-2 strain on the growth of $B$. cereus strains at different time in NGKG agar at $35^{\circ} \mathrm{C}$ for $44 \mathrm{~h}$.

pathogens, a variety of techniques have been evaluated including Nisin like antibiotic substances and chemical, heat, enzymatic, and acid treatments [2]. In general, Bacillus subtilus is the most dominant bacterium in fermented soybean [9]. Some Bacillus subtilis have been reported to produce bacteriocins which suppress the growth of Gram positive spoilage and pathogenic bacteria $[7,8]$.

\subsection{Check the Quality of SEING Produced by} Antimicrobial Bacillus subtilis Strain

The time and temperature play a vital role in bacteriocin production. Therefore, the modification test was conducted using cooked soybean mixed with culture B. CeM6-2 and B. cereus in ratio, the mixtures were fermented at room temperature (RT) with different timing ( 0 h, 24 h, $48 \mathrm{~h}$ and $72 \mathrm{~h}$ ). Within the expectation, B. CeM6-2 is capable to produce bacteriocin to fight against $B$. cereus indicator strains finally in fermented soybean in Table 3.

The characteristics of antimicrobial activity against $B$. cereus of seven different concentrations ratio with B. CeM6-2 strain, after cultured in Bacillus-fermented soybean contained against $B$. cereus $(\mathrm{OD}=0.1)$, were discussed in Table 3. The table indicated that at $24 \mathrm{~h}$ all of strains, except B. CeM6-2 + B. cereus in ratio 10:0 $\mathrm{mL}$ strain, had antimicrobial activity. Nevertheless, at $48 \mathrm{~h}$ and $72 \mathrm{~h}$, only two concentrations ratio strains $B$. CeM6- $2+B$. cereus (10:0 mL) and B. CeM6-2 + B. cereus $(9: 1 \mathrm{~mL})$ were able to inactivate Bacillus-fermented soybean contained against $B$. cereus. At these two timing, $48 \mathrm{~h}$ and $72 \mathrm{~h}$, B. CeM6-2 + B. cereus $(10: 0 \mathrm{~mL})$ strain showed the most powerful antimicrobial action compared to other concentrations ratio strains. The seven different concentration ratio strains B. CeM6-2 cultured growing between $6.00 \log 10 \mathrm{CFU} / \mathrm{g}$ at $0 \mathrm{~h}$. At $24 \mathrm{~h}$, the five concentration ratio antimicrobial strains were developed similarly between 4.55 and $4.95 \log 10$ $\mathrm{CFU} / \mathrm{g}$ which is less than concentration ratio $B$. CeM6-2 + B. cereus $(0: 10 \mathrm{~mL})$ and B. CeM6-2 + B. cereus $(3: 7 \mathrm{~mL})$ strain in fermented soybean calculated to be $5.09 \log 10 \mathrm{CFU} / \mathrm{g}$ to $5.41 \log 10$ $\mathrm{CFU} / \mathrm{g}$. At $48 \mathrm{~h}$ and $72 \mathrm{~h}$ striking in NGKG agar plate, two concentrations ratio strains B. CeM6-2 $+B$. cereus $(10: 0 \mathrm{~mL})$ and B. CeM6-2 + B. cereus $(9: 1 \mathrm{~mL})$ were counted at 2.71-3.63 $\log 10 \mathrm{CFU} / \mathrm{g}$ and 3.05-3.37 $\log 10 \mathrm{CFU} / \mathrm{g}$ that are higher suppression than the other 

and Safety of Fermented Soybean (SIENG) Produced in Cambodia

Table 3 Application of bacteriocin produced by $B$. CeM6-2 strain to control the growth of $B$. cereus in fermented soybean by $\log \mathrm{CFU} / \mathrm{g}$ at different time and room temperature.

\begin{tabular}{|c|c|c|c|c|c|c|c|c|}
\hline \multirow{2}{*}{$\begin{array}{l}\text { Number of mix of both Bacillus } \\
\text { strains }\end{array}$} & \multicolumn{2}{|r|}{$0 \mathrm{~h}$} & \multicolumn{2}{|c|}{$24 \mathrm{~h}$} & \multicolumn{2}{|c|}{$48 \mathrm{~h}$} & \multicolumn{2}{|c|}{$72 \mathrm{~h}$} \\
\hline & $\mathrm{CFU} / \mathrm{g}$ & $\log \mathrm{CFU} / \mathrm{g}$ & $\mathrm{CFU} / \mathrm{g}$ & $\log \mathrm{CFU} / \mathrm{g}$ & CFU/g & $\log C F U / g$ & CFU/g & $\log \mathrm{CFU} / \mathrm{g}$ \\
\hline B. CeM6-2 + B. cereus $(10: 0 \mathrm{~mL})$ & $1 \times 10^{6}$ & 6.00 & $3.52 \times 10^{4}$ & 4.55 & $5.17 \times 10^{2}$ & 2.71 & $1.13 \times 10^{3}$ & 3.05 \\
\hline B. CeM6-2 + B. cereus $(0: 10 \mathrm{~mL})$ & $1 \times 10^{6}$ & 6.00 & $2.59 \times 10^{5}$ & 5.41 & $3.08 \times 10^{5}$ & 5.49 & $4.93 \times 10^{5}$ & 5.69 \\
\hline B. CeM6-2 + B. cereus $(9: 1 \mathrm{~mL})$ & $1 \times 10^{6}$ & 6.00 & $5.48 \times 10^{4}$ & 4.74 & $4.23 \times 10^{3}$ & 3.63 & $2.35 \times 10^{3}$ & 3.37 \\
\hline B. CeM6-2 + B. cereus $(1: 9 \mathrm{~mL})$ & $1 \times 10^{6}$ & 6.00 & $8.95 \times 10^{4}$ & 4.95 & $3.93 \times 10^{5}$ & 5.59 & $2.57 \times 10^{5}$ & 5.41 \\
\hline B. CeM6-2 + B. cereus $(5: 5 \mathrm{~mL})$ & $1 \times 10^{6}$ & 6.00 & $7.85 \times 10^{4}$ & 4.89 & $3.93 \times 10^{5}$ & 5.59 & $4.39 \times 10^{5}$ & 5.64 \\
\hline B. CeM6-2 + B. cereus $(7: 3 \mathrm{~mL})$ & $1 \times 10^{6}$ & 6.00 & $5.69 \times 10^{4}$ & 4.76 & $3.35 \times 10^{5}$ & 5.52 & $1.44 \times 10^{5}$ & 5.16 \\
\hline B. CeM6-2 + B. cereus $(3: 7 \mathrm{~mL})$ & $1 \times 10^{6}$ & 6.00 & $1.24 \times 10^{5}$ & 5.09 & $4.17 \times 10^{5}$ & 5.62 & $4.46 \times 10^{5}$ & 5.65 \\
\hline
\end{tabular}

five concentration ratio strains existing between 5.52-5.62 $\log 10 \mathrm{CFU} / \mathrm{g}$ and 5.16-5.66 $\log 10 \mathrm{CFU} / \mathrm{g}$. Together with report of $B$. subtilis HJ18-4, which also exhibited strong antibacterial activity against Bacillus cereus, and also found that water extracts of soy product fermented with $B$. subtilis HJ18-4 significantly inhibited the growth of $B$. cereus and toxin expression [15]. The bacteriocins produced by these strains are thought to be potent food preservatives that are applicable for Cambodian food.

\section{Conclusion}

Fermented foods are commonly found in Cambodia and in other Asia countries since they play a very important role for health, especially in developing countries. In the processing procedure, SIENG naturally contains various kinds of microorganisms including useful microorganism and pathogenic microorganism. So, the use of good starter culture like $B$. subtilis can ensure the safety and stability of the products.

In this work, we demonstrated the diversity of $B$. cereus in SIENG, a Cambodian's traditional fermented soybean food. Out of 120 SIENG samples, 49 samples of $B$. cereus strains were isolated and there were only 12 of $B$. cereus that gave positive sensitivity compared with control enterotoxin by lyophilization and then 2 (BTM8-7 and BTM8-8) of these 12 isolated Bacillus cereus strain produced the highest level enterotoxin, which may cause diarrhea, vomiting and nausea a few hours after consumption of contaminated food.
One hundred and twenty (120) samples SIENG were found only 5 of Bacillus strains that have ability to fight against the indicator microorganisms Lactobacillus plantarum ATCC 8014 by agar well diffusion assay and among 5 samples, only one strain (Bacillus CeM6-2) has shown a great active zone against Lactobacillus plantarum. B. CeM6-2 strain could tolerate with heat up to $20 \mathrm{~h}$ at $30{ }^{\circ} \mathrm{C}$ temperature and $22 \mathrm{~h}$ at $37{ }^{\circ} \mathrm{C}$. Besides, bacteriocin produced by $B$. CeM6-2 untreated and $B$. CeM6-2PK-PMSF has more ability to suppress all the indicators starting from $0 \mathrm{~h}$ to $47 \mathrm{~h}$ compared with $B$. CeM6-2PK strain at a very significant level. Moreover, Bacillus CeM6-2 strain performed very well when treated with Gram positive group, against Listeria monocytogenes, and Streptococcus pyrogene and lactic acid groups, against Leuconostoc mesenterids and L. plantarum at a very extensive level. Bacillus CeM6-2 strain has higher strength unlike Japanese strains (Miyagino) from 0-58 h and 0-40 h incubation time.

In similar finding to the prior test of co-cultivate Bacillus cereus and Bacillus subtilis at $35^{\circ} \mathrm{C}, 44 \mathrm{~h}$ CeM6-2 (1\%) strain had the highest ability to fight against $B$. cereus indicator strain beginning from $24 \mathrm{~h}$ incubation and it was best to suppress $B$. cereus indicator at $34 \mathrm{~h}$ to $44 \mathrm{~h}$ incubation as well. However, to check the quality of SEING produced by antimicrobial Bacillus CeM6-2 strain, two concentrations ratio strains $B$. CeM6- $2+B$. cereus $(10: 0 \mathrm{~mL})$ and $B$. CeM6-2 + B. cereus $(9: 1 \mathrm{~mL})$ have 


\section{Application of Antimicrobial Bacillus subtilis Strain as a Starter Culture to Improve Qualities and Safety of Fermented Soybean (SIENG) Produced in Cambodia}

the strongest power to fight against $B$. cereus indicator strain at both room temperature time (48 h and $72 \mathrm{~h}$ ). In the meantime, $B$. CeM6-2 strain produced the largest amount of bateriocin to inactivate $B$. cereus indicator at $24 \mathrm{~h}$ to $72 \mathrm{~h}$ incubation and room temperature as well. It means that, the longer incubation and room temperature time (in specific timing), the higher bacteriocin. Thus, this property of bacteriocins produced by Bacillus CeM6-2 can be used as a preservative in food processing industries to avoid food spoilage even in higher temperature and time.

\section{Acknowledgement}

This research activity is a Follow-Up Research of the UNU-Kirin Fellowship Programme at the Royal University of Agriculture, Phnom Penh, Cambodia in 2016-2017, supported by UNU-IAS Program, Tokyo, Japan.

\section{References}

[1] Oliver, S. P., Jayarao, B. M., and Almeida, R. A. 2005. "Food-Borne Pathogens in Milk and the Dairy Farm Environment: Food Safety and Public Health Implications.” Foodborne Pathog Dis 2 (2): 115-29.

[2] Yeo, I. C., Lee, N. K., Cha, C. J., and Hahm, Y. T. 2011. "Narrow Antagonistic Activity of Antimicrobial Peptide from Bacillus subtilis SCK-2 against Bacillus cereus.” J Biosci Bioeng 112: 338-44.

[3] Kim, H., Kim, H., Bang, J., Kim, Y., Beuchat, L. R., and Ryu, J. H. 2012. "Reduction of Bacillus cereus Spores in Sikhye, a Traditional Korean Rice Beverage, by Modified Tyndallization Processes with and without Carbon Dioxide Injection.” Lett Appl Microbiol 55: 218-23.

[4] Royal Government of Cambodia. 2013. "Rectangular Strategy for Growth, Employment, Equity and Efficiency Phase III.” The Royal Government of Cambodia of the Fifth Legislature of the National Assembly.

[5] Sopheap, E., and Yasuhiro, I. 2016. "Isolation, Characterization and Bio-control Activities of Bacillus subtilis from in Fermented Soybean in Cambodia.” Final Report of NFRI-UNU-KIRIN Fellowship Program
(2015-2016), pp. 1-34.

[6] Inatsu, Y., Hosotani, Y., Ananchaipattana, C., Hoque, M. M., and Thong, K. 2012. "Distribution of Bacteriocin Producing Bacillus subtilis Strains Effective for Controlling Pathogenic/Spoilage Gram-positive Bacteria in Asian Countries.” 477-1017.

[7] Khochamit, N., Siripornadulsil, S., Sukon, P., and Siripornadulsil, W. 2014. "Antibacterial Activity and Genotypic-Phenotypic Characteristics of Bacteriocin Producing Bacillus subtilis KKU213: MICRES 25708." Microbiological Research (14): 1-47. http://dx.doi.org/10.1016/j.micres.2014.09.004.

[8] Wang, T., Liang, Y., Wu, M., Chen, Z., Lin, J., and Yang, L. 2015. "Natural Products from Bacillus subtilis with Antimicrobial Properties." Chinese Journal of Chemical Engineering 23 (4): 1-28.

[9] Pedersen, P. B., Bjrnvad, M. E., Rasmussen, M. D., and Petersen, J. N. 2002. "Cytotoxic Potential of Industrial Strains of Bacillus sp.” Regul. Toxicol. Pharm. 36 (2): 155-61.

[10] TAKARA BIO INC. "Bacillus cereus (CRS gene) PCR Detection Kit.” Cat.\# RR132A, v.0703, pp. 2-7. http://www.takara.co.kr/file/manual/pdf/RR132A_e.v070 3.pdf.

[11] Cetin-Karaca, H. 2011. "Evaluation of Natural Antimicrobial Phenolic Compounds against Foodborne Pathogens.” Master's thesis, University of Kentucky.

[12] Inatsu, Y., Nakamura, N., Yuriko, Y., Fushimi, T., Watanasiritum, L., and Kawamoto, S. 2006. "Characterization of Bacillus subtilis Strains in Thua Nao, a Traditional Fermented Soybean Food in Northern Thailand.” Letters in Applied Microbiology 43 (3): 237-42.

[13] Efendi, Y., and Yusra, Y. 2014. "Bacillus subtilis Strain VITNJ1 Potential Probiotic Bacteria in the Gut of Tilapia (Oreochromis niloticus) Are Cultured in Floating Net, Maninjau Lake, West Sumatra.” Pakistan Journal of Nutrition 13 (12): 710-5.

[14] Askoul, I., Gorrah, S. A., and Al-Amir, L. 2014. "Isolation and Characterization of Bacteriocin Producing Lactic Acid Bacteria from Some Syrian Fermented Foods.” International Journal of ChemTech Research 6 (4): 2507-20.

[15] Eom, J. S., Lee, S. Y., and Choi, H. S. 2014. "Bacillus subtilis HJ18-4 from Traditional Fermented Soybean Food Inhibits Bacillus cereus Growth and Toxin-Related Genes.” Journal of Food Science, M2279-87. 